\title{
Hydrogeology and Water Quality of the Shallow Aquifer System at the Explosive Experimental Area, Naval Surface Warfare Center, Dahlgren Site, Dahlgren, Virginia
}

By Clifton F. Bell

U.S. GEOLOGICAL SURVEY

Water-Resources Investigations Report 96-4209

Prepared in cooperation with the

ENVIRONMENTAL AND SAFETY OFFICE NAVAL SURFACE WARFARE CENTER, DAHLGREN SITE 


\section{U.S. DEPARTMENT OF THE INTERIOR BRUCE BABBITT, Secretary \\ U.S. GEOLOGICAL SURVEY Gordon P. Eaton, Director}

For additional information write to:

District Chief

U.S. Geological Survey 3600 West Broad Street, Room 606

Richmond, VA 23230-4916
Copies of this report can be purchased from:

U.S. Geological Survey

Branch of Information Services

Box 25286

Denver, CO 80225-0286 


\section{CONTENTS}

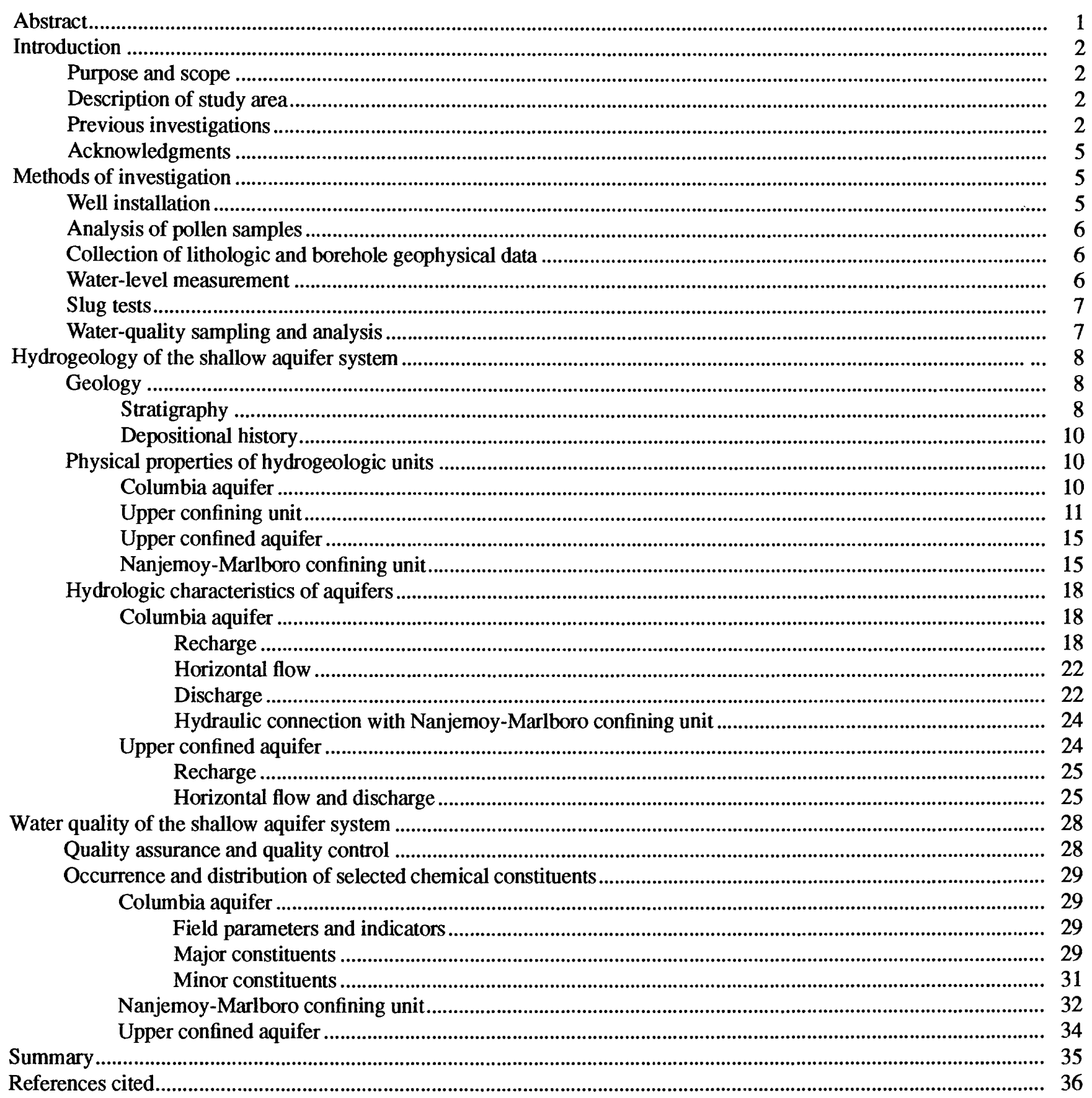

\section{FIGURES}

1,2. Maps showing:

1. Location of study area .

2. Locations of observation wells and surface-water sampling sites 
3. Schematic diagram of geologic and hydrogeologic units of the shallow aquifer system

4. Hydrogeologic map showing altitude of bottom and thickness of the Columbia aquifer

5. Boxplots showing distribution of horizontal and vertical hydraulic conductivity of hydrogeologic units

6. Hydrogeologic section $A-A^{\prime}$..

7-11. Hydrogeologic maps showing:

7. Thickness and altitude of upper confining unit.

8. Altitude of top and thickness of upper confined aquifer....................................................................... 17

9. Altitude of top of Nanjemoy-Marlboro confining unit ......................................................................... 19

10. Potentiometric surface of the Columbia aquifer, March 1994 ................................................................ 20

11. Potentiometric surface of the Columbia aquifer, December 1994 ...................................................... 21

12-14. Graphs showing maximum daily water levels in the Columbia aquifer for:

12. Well EEA-S1 and precipitation data, April 1994 through March 1995.

13. Well cluster 4 and synoptic water-level measurements for well clusters 5 and 7 , April 1994 through April 1995

14. Wells EEA-S 12 and EEA-S13, April 1994 through March 1995.......................................................... 24

15. Graph showing water level in the Columbia aquifer for well EEA-S1 July 11-15, 1995

16. Hydrogeologic map showing potentiometric surface in the upper confined aquifer and the NanjemoyMarlboro confining unit, March 1994

17. Hydrogeologic map showing potentiometric surface in the upper confined aquifer and the NanjemoyMarlboro confining unit, December 1994

18. Hydrograph showing water levels for wells EEA-M3, M6, M8, and tidal fluctuations in the Upper Machodoc Creek, August 1-5, 1995.

19. Boxplot summaries of water-quality analyses for selected constituents in ground water .

20, 21. Trilinear diagram showing major-ion composition of water from wells completed in the:

20. Columbia aquifer

21. Upper confined aquifer and Nanjemoy-Marlboro confining unit

\section{TABLES}

1. Horizontal hydraulic conductivities determined from slug tests at the Explosive Experimental Area, Dahlgren, Virginia

2. Summary statistics for water-quality analyses from the Columbia aquifer at the Explosive Experimental Area, Dahlgren, Virginia. 

CONVERSION FACTORS, VERTICAL DATUM, AND ABBREVIATED WATER-
QUALITY UNITS

\begin{tabular}{rcl}
\hline Multiply & By & To obtaln \\
\hline & Length & \\
\hline inch (in.) & 25.4 & millimeter (mm) \\
foot (ft) & 0.3048 & meter \\
mile (mi) & 1.609 & kilometer \\
\hline acre & 4,047 & \\
\hline & Volume & square meter \\
\hline gallon & 3.785 & liter (L) \\
gallon & 3,785 & milliliter (mL) \\
\hline & Hydraulic conductivty & \\
\hline foot per day (ft/d) & 0.3048 & meter per day \\
\hline
\end{tabular}

${ }^{1} \mathrm{~A}$ mathematical reduction of the unit cubic foot per day per square foot $\left[\left(\mathrm{ft}^{3} / \mathrm{d}\right) / \mathrm{ft}^{2}\right]$.

Sea level: In this report, "sea level" refers to the National Geodetic Vertical Datum of 1929-a geodetic datum derived from a general adjustment of the first-order level nets of the United States and Canada, formerly called Sea Level Datum of 1929.

Abbreviated water-quality units: Chemical concentration is reported in milligrams per liter $(\mathrm{mg} / \mathrm{L})$ or micrograms per liter $(\mu \mathrm{g} / \mathrm{L})$. Milligrams per liter is a unit expressing the concentration of chemical constituents in solution as weight (milligrams) of solute per unit volume (liter) of water. One thousand micrograms per liter is equivalent to one milligram per liter. For concentrations less than $7,000 \mathrm{mg} / \mathrm{L}$, the numerical value is the same as for concentrations in parts per million. Specific electrical conductance of water is reported in microsiemens per centimeter at 25 degrees Celsius $(\mu \mathrm{S} / \mathrm{cm})$. Water temperature is reported in degree Celsius $\left({ }^{\circ} \mathrm{C}\right)$, which can be converted to degree Fahrenheit $\left({ }^{\circ} \mathrm{F}\right)$ by the following equation:

$$
{ }^{\circ} \mathrm{F}=1.8\left({ }^{\circ} \mathrm{C}\right)+32
$$




\title{
Hydrogeology and Water Quality of the Shallow Aquifer System at the Explosive Experimental Area, Naval Surface Warfare Center, Dahlgren Site, Dahlgren, Virginia
}

\author{
By Clifton F. Bell
}

\section{Abstract}

In October 1993, the U.S. Geological Survey began a study to characterize the hydrogeology of the shallow aquifer system at the Explosive Experimental Area, Naval Surface Warfare Center, Dahlgren Site, Dahlgren, Virginia, which is located on the Potomac River in the Coastal Plain Physiographic Province. The study provides a description of the hydrogeologic units, directions of ground-water flow, and background water quality in the study area to a depth of about 100 feet. Lithologic, geophysical, and hydrologic data were collected from 28 wells drilled for this study, from 3 existing wells, and from outcrops.

The shallow aquifer system at the Explosive Experimental Area consists of two finingupward sequences of Pleistocene fluvial-estuarine deposits that overlie Paleocene-Eocene marine deposits of the Nanjemoy-Marlboro confining unit. The surficial hydrogeologic unit is the Columbia aquifer. Horizontal linear flow of water in this aquifer generally responds to the surface topography, discharging to tidal creeks, marshes, and the Potomac River, and rates of flow in this aquifer range from 0.003 to 0.70 foot per day.

The Columbia aquifer unconformably overlies the upper confining unit-an organic-rich clay that is 0 to 55 feet thick. The upper confining unit conformably overlies the upper confined aquifer, a $\mathbf{0}$ - to 35 -feet thick unit that consists of interbedded fine-grained to medium-grained sands and clay. The upper confined aquifer probably receives most of its recharge from the adjacent and underlying Nanjemoy-Marlboro confining unit. Water in the upper confined aquifer generally flows eastward, northward, and northeastward at about 0.03 foot per day toward the Potomac River and Machodoc Creek.

The Nanjemoy-Marlboro confining unit consists of glauconitic, fossiliferous silty finegrained sands of the Nanjemoy Formation. Where the upper confined system is absent, the Nanjemoy-Marlboro confining unit is directly overlain by the Columbia aquifer. In some parts of the Explosive Experimental Area, horizontal hydraulic conductivities of the NanjemoyMarlboro confining unit and the Columbia aquifer are similar (from $10^{-4}$ to $10^{-2}$ foot per day), and these units effectively combine to form a thick (greater than 50 feet) aquifer.

The background water quality of the shallow aquifer system is characteristic of ground waters in the Virginia Coastal Plain Physiographic Province. Water in the Columbia aquifer is a mixed ionic type, has a median $\mathrm{pH}$ of 5.9 , and a median total dissolved solids of 106 milligrams per liter. Water in the upper confined aquifer and Nanjemoy-Marlboro confining unit is a sodiumcalcium-bicarbonate type, and generally has higher $\mathrm{pH}$, dissolved solids, and alkalinity than water in the Columbia aquifer. Water in the upper confined aquifer and some parts of the Columbia aquifer is anoxic, and it has high concentrations of dissolved iron, manganese, and sulfide. 


\section{INTRODUCTION}

The Naval Surface Warfare Center, Dahlgren Site (NSWCDL) at Dahlgren, Va. (fig. 1), was established in 1918 as a proving ground for naval ordnance. At present (1996) the NSWCDL is the U.S. Navy's primary center for research, development, and testing of offensive and defensive systems associated with surface/ship warfare. The Explosive Experimental Area (EEA) of the NSCWDL, located to the south of Machodoc Creek (fig. 2), is used primarily for testing and evaluation of naval ordnance. Through the Installation Restoration Program, the U.S. Navy currently is evaluating the EEA for potential contamination of ground water, soil, and surface water caused by various activities conducted during the history of the installation.

In 1993, the U.S. Geological Survey (USGS) began a hydrogeologic framework investigation of the shallow aquifer system underlying the EEA. The study was designed to provide the U.S. Navy with basic hydrogeologic and water-quality data and with a description of the natural properties and characteristics of the shallow aquifer system. Results from this investigation can be used by the NSWCDL to assist Installation Restoration activities and to provide a basis for future planning of operations that have the potential to affect the shallow aquifer system. Characterization of individual contaminated sites was not an objective of this study.

\section{Purpose and Scope}

The purpose of this report is to describe the hydrogeology and background water quality of the shallow aquifer system at the EEA, NSWCDL, Dahlgren, Va. The shallow aquifer system is defined in this report as the hydrogeologic units present beneath the study area to a depth of approximately $100 \mathrm{ft}$ below land surface.

The report includes a discussion of the (1) physical properties, (2) hydrology, and (3) water quality of the shallow aquifer system. Water-level measurements were collected monthly or continuously from March 1994 through April 1995 at 28 wells drilled for this study and 1 existing well. Water-quality samples were collected from these 28 wells and from 3 surfacewater locations in June 1994. Other sources of data include lithologic samples, pollen samples, geophysical logs, and aquifer-test data from 28 wells drilled for this study, and lithologic samples from outcrops and 2 existing boreholes. The interpreted hydrogeologic framework is illustrated in maps and a hydrogeologic section, and an assessment of ground-water quality is provided by tabular and graphical summaries.

\section{Description of Study Area}

The NSWCDL is located along the Potomac River in King George County, Va. (fig. 1), and it is divided by Machodoc Creek into two parts: (1) the Mainside of 2,678 acres to the north; and (2) the EEA of 1,614 acres to the south of Machodoc Creek. The EEA is bounded to the north and west by Machodoc Creek and to the east by the Potomac River. The study area lies in the Coastal Plain Physiographic Province of Virginia.

Land surface is generally flat at the EEA, and elevations range from 0 to $30 \mathrm{ft}$ above sea level. The EEA lies on a terrace on the riverward side of a major scarp, called the Dahlgren scarp in this report, that rises more than $100 \mathrm{ft}$ above the elevation of the terrace. Land cover at the EEA is forest, open field, marsh, and military operations facilities. Surfacewater bodies on the EEA include Black Marsh and several unnamed tributaries to Machodoc Creek.

\section{Previous Investigations}

An Initial Assessment Study (IAS) of the NSWCDL was begun in 1981 (Fred C. Hart Associates, 1983). The IAS identified 10 potentially contaminated sites at the EEA; however, Confirmation Studies were not recommended for any of these sites (O'Brien and Gere, 1986). The U.S. Environmental Protection Agency has since designated nine sites at the EEA as Solid Waste Management Units (areas where solid wastes may have been released, even if the areas were not intended for the management of solid or hazardous wastes) or Areas of Concern. An annual Site Management Plan (Halliburton NUS, 1995) estimated schedules for conducting Comprehensive Environmental Response, Compensation, and Liability Act activities. The USGS began a hydrogeologic framework investigation of the Mainside of the NSWCDL in 1992; results from that study are presented in a data report (Bell and others, 1994) and in an interpretive report (Harlow and Bell, 1996). 


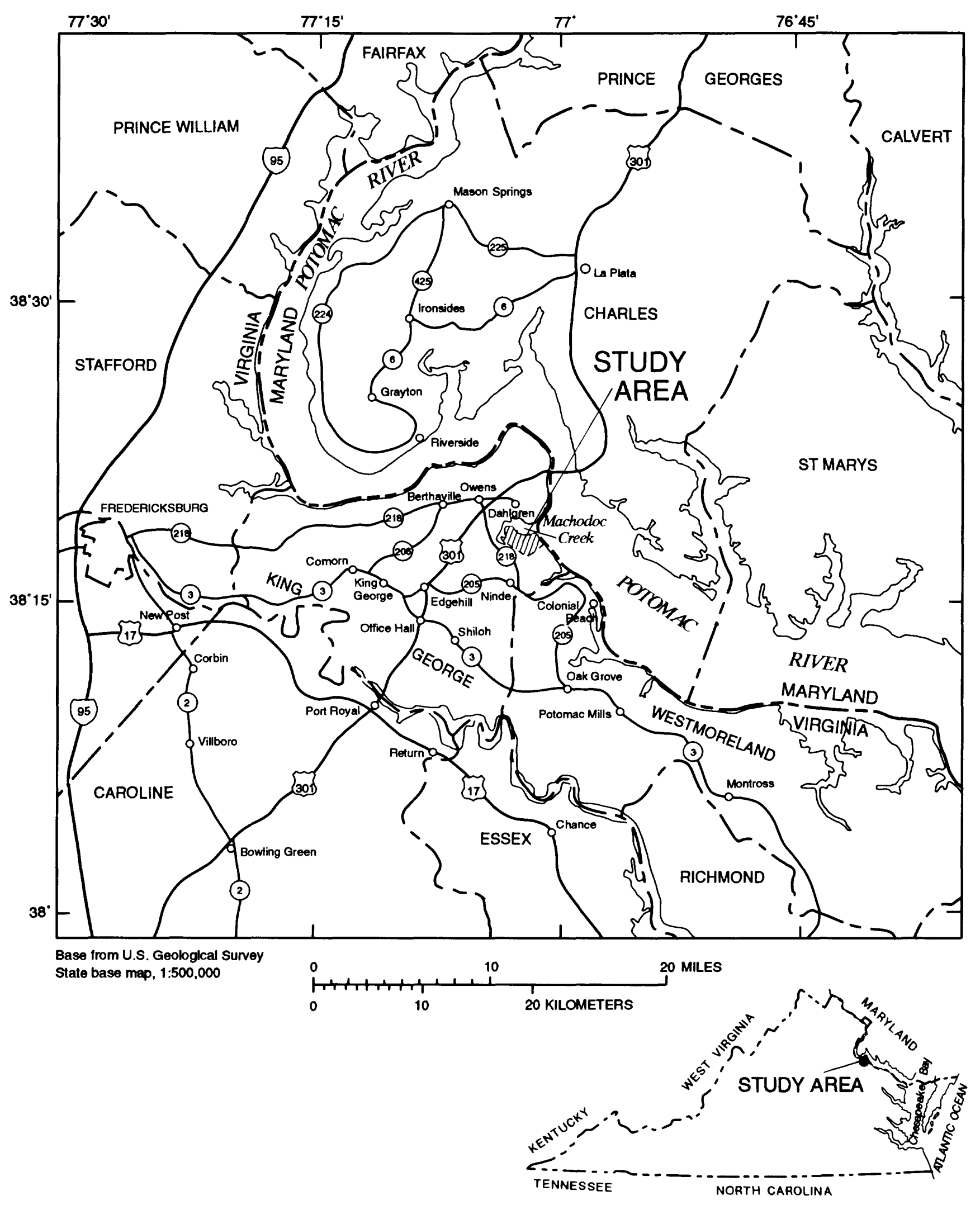

Figure 1. Location of study area at the Explosive Experimental Area, Dahlgren, Virginia. 


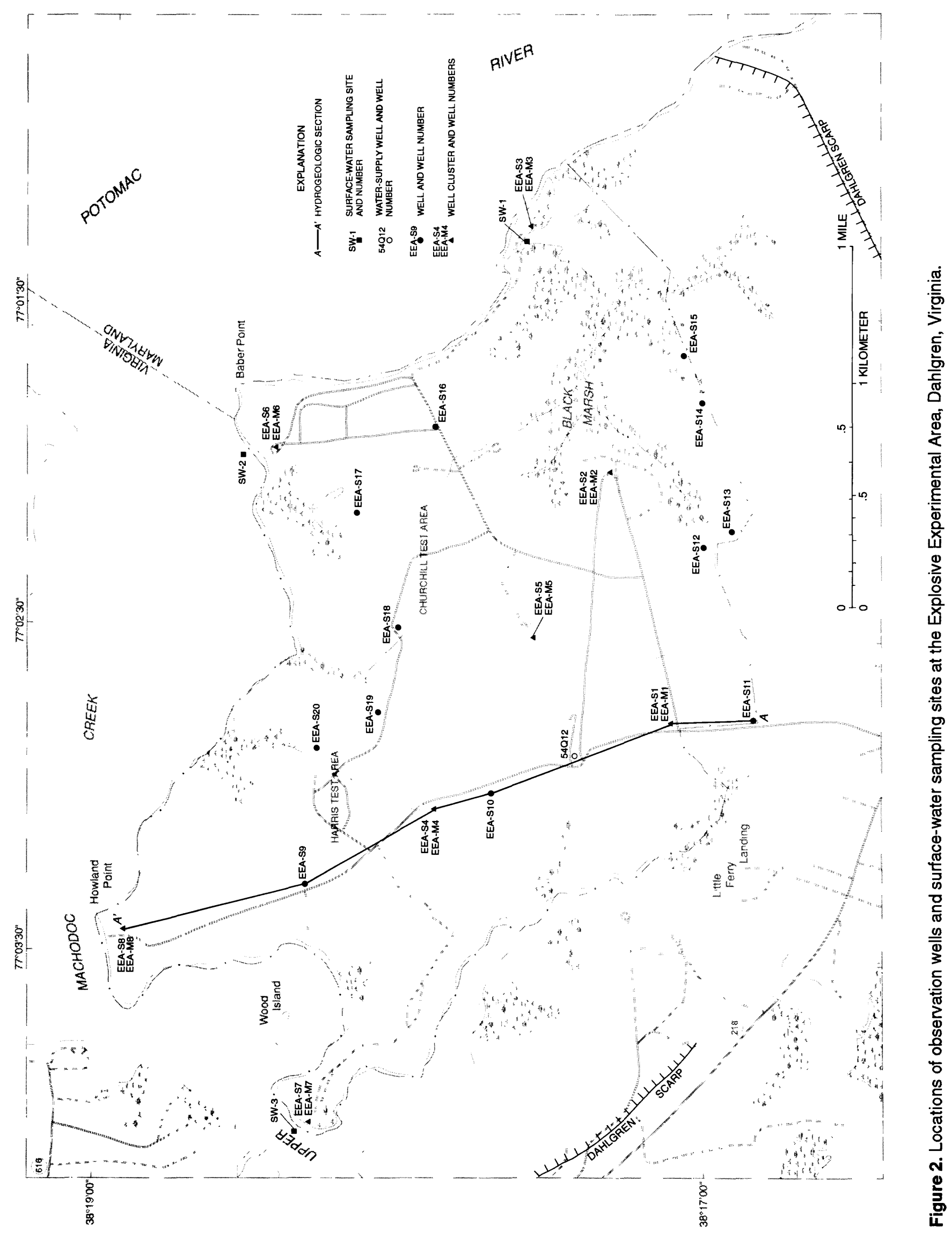


Meng and Harsh (1988) define and provide an overview of the hydrogeologic framework of the Virginia Coastal Plain as part of the USGS Regional Aquifer System Analysis (RASA) of the northern Atlantic Coastal Plain. A subsequent RASA report (Harsh and Laczniak, 1990) describes the results of numerical modeling of the ground-water-flow system in the Virginia Coastal Plain. Mixon and others (1989) mapped the geology of the Virginia Coastal Plain and adjacent parts of the Piedmont. Numerous researchers (Schubel and Zabawa, 1973; Kerhin and others, 1980; Shideler and others, 1984; Colman and Mixon, 1988; Colman and others, 1990) have noted and described Pleistocene fluvial channel deposits associated with the ancestral Susquehanna River and its tributaries.

\section{Acknowledgments}

The author wishes to thank Ann Swope, Billie Weedon, Collins Johnson, and other members of the Safety and Environmental Office, NSWCDL, for their assistance in planning and implementation of this study. James DeShazo, EEA facilities manager, and Robert Hoyer assisted in the coordination of activities at the EEA. The U.S. Army COE completed the drilling operations at the EEA in a safe and efficient manner under the supervision of Charles Brown, and conducted the laboratory analysis of Shelby tube samples under the direction of David P. Hammer. The author also would like to thank Dr. Grace S. Brush of the Johns Hopkins University for the pollen analysis, and Dr. Richard Berquist of the Virginia Division of Mineral Resources and Dr. Gerald H. Johnson of the College of William and Mary whose geologic insights were much appreciated. Special thanks are extended to Daniel R. Conrad, formerly of the USGS, who performed much of the field work for this study.

\section{METHODS OF INVESTIGATION}

The hydrogeology and water quality of the shallow aquifer system at the EEA were investigated by use of field and laboratory procedures that are described in this section. Hydrogeologic and waterquality data collected for this investigation are presented in a separate data report (Hammond and Bell, 1995). Well-construction data and periodic water-level measurements are stored in the USGS GroundWater-Site-Inventory file, a storage and retrieval system that is part of the National Water Information System (NWIS). The continuous ground-water-level data are stored in the USGS Automated Data Processing System (ADAPS), which also is part of NWIS. The original field notebooks and hard copies of all well-construction, water-level, and water-quality data are stored at the Virginia District office of the USGS.

\section{Well Installation}

On the basis of a hydrogeologic assessment of the Mainside (Harlow and Bell, 1996), 20 wells were drilled and completed in the Columbia aquifer and 8 wells were completed in the upper confined aquifer for this study. Each of the eight confined aquifer wells were to be clustered with a well in the shallow Columbia aquifer. Beneath four of the cluster sites, however, the thick sands typical of the upper confined aquifer on the Mainside were not present; therefore, at these clusters, the deeper wells were completed in the Nanjemoy-Marlboro confining unit. Well locations (fig. 2) were chosen to obtain maximum areal coverage of the EEA, to have drill sites accessible by drilling equipment, and to avoid areas of known or suspected contamination.

All 28 observation wells installed at the EEA for the hydrogeologic assessment were constructed of 4-in. inside-diameter polyvinyl chloride (PVC) casing. Of the 20 wells completed in the Columbia aquifer 17 were augered, and 3 (wells EEA-S6, -S8, -S11) were drilled by the hydraulic rotary method. Four wells were completed in the upper confined aquifer and four wells were completed in the Nanjemoy-Marlboro confining unit by the hydraulic rotary method. In order to avoid possible contamination of the confined aquifers from the Columbia aquifer during drilling, 10-in. inside-diameter PVC casing was set and grouted into the upper confining unit before drilling continued through the aquifer below. An additional well, called FCOT-4, was completed in the Columbia aquifer for another project but was utilized for the hydrogeologic assessment described here.

Wells in the Columbia aquifer were constructed with 5-, 10-, and15-ft screens; wells in the upper confined aquifer were constructed with 10-ft screens; and wells in the Nanjemoy-Marlboro confining unit were constructed with $10-\mathrm{ft}$ screens. Centralizers made of stainless steel were placed at the top and bottom of the well screens. Details on the construction of individual wells are presented in Hammond and Bell (1995). 
Pollen samples from selected core intervals were analyzed to distinguish among Pleistocene and older deposits. Because of the widely different depositional settings of Pleistocene and Tertiary marine sediments, age information is important in interpreting the lateral and vertical extent of the different geologic units.

Twelve sediment samples, representing all four hydrogeologic units observed in the shallow aquifer system, were collected by use of Shelby tubes or splitspoon samplers. The samples were sent to the Department of Geography and Environmental Engineering at the Johns Hopkins University for pollen analysis. In order to extract pollen from sediment, a measured volume of sediment was washed in strong acid, and acetylzed to remove carbonates, silicates, and organic material. The residue was washed in acetic acid, distilled water, and alcohol, and then it was stored in tertiary butyl alcohol. Aliquots of $0.2 \mathrm{~mL}$ were mounted in silicone oil on microscopic slides, and all pollen in the aliquot was identified and counted under $\times 400$ (magnification) (G. Brush, Johns Hopkins University, oral commun., 1995).

\section{Collection of Lithologic and Borehole Geophysical Data}

The extent and thickness of hydrogeologic units at the EEA were determined by interpretation of lithologic and borehole geophysical data. Sediment samples were recovered with split-spoon samplers, and lithologic descriptions were logged during drilling operations at 20 wells. Lithologic characteristics recorded include grain size, color, textures, sedimentary structures, degree of moistness, and the presence of organic material, shell material, indurated material, glauconite, or mica. In some intervals, macro-fossils were recovered and identified to aid in the geologic interpretation. In addition to split spoon samples, 36 Shelby tube cores from 18 well sites were analyzed for vertical hydraulic conductivity and mineralogy by the U.S. Army Corps of Engineers (COE), Ohio River Division Laboratory, Cincinnati, Ohio. Vertical hydraulic conductivity was measured by the fallinghead permeameter method. Mineralogy was determined by visual inspection and $\mathrm{x}$-ray diffraction. The core intervals were chosen to characterize vertical and areal variations in lithology.
Geophysical logs were recorded at all drill sites (Hammond and Bell, 1995). A probe was lowered to the bottom of the borehole and the geophysical response was recorded as the probe was raised. Natural gamma-radiation, spontaneous potential, singlepoint resistance, 16-in. normal resistivity, and 64-in. normal resistivity logs were run at boreholes for wells completed in the upper confined aquifer and Nanjemoy-Marlboro confining unit, prior to installation of the casing. Natural gamma-radiation and electromagnetic (EM) induction conductivity logs were run at all wells after installation of the casing. Along certain intervals in the wells, the EM induction conductivity signal was affected by metal centralizers.

\section{Water-Level Measurement}

Continuous water-level data were collected from March 1994 through April 1995 and used to observe seasonal and short-term variations in water levels. The water-level data allow direct comparison of the effects of tidal influences, precipitation events, and evapotranspiration on water levels in different aquifers. Analog-to-digital recorders (ADR's) were completed on 10 wells (EEA-M1, S1, M3, S3, M4, S4, M6, S6, M8, and S8) to monitor the water levels. The ADR's recorded measurements every hour. Measurements of tidal fluctuations were collected by the USGS from a tide gage completed on the north side of Upper Machodoc Creek.

Water levels were measured monthly at each of the 28 wells completed for this study (Hammond and Bell, 1995) and at well FCOTS-4. Measuring points were established for each well on the top of the casing; the elevations of these wells were surveyed by the USGS from a first-order bench mark to an accuracy of $0.01 \mathrm{ft}$. Water-levels in wells were measured to an accuracy of $0.01 \mathrm{ft}$ by chalked steel tape. 'These measurements were then subtracted from the elevations of the respective measuring points to obtain the elevations of the water levels. Maps were constructed that depict hydraulic-head contours for the high-water and low-water periods of the year. Water-level data also were used to determine horizontal and vertical hydraulic-head gradients. 


\section{Slug Tests}

Slug tests, by the volume-displacement method, were conducted on all 28 wells to determine horizontal hydraulic conductivity. An In-Situ Hermit (1000B) data logger and pressure transducer were used to record the water levels. Prior to the introduction of the slug, the water level was monitored for 10 minutes so that any rising or falling background trend could be established and subtracted from the water-level recovery. The slug was introduced by a sand-filled PVC cylinder of known volume. The cylinder was rapidly lowered into the well, causing a temporary rise in the water level. The data logger recorded the rise and the ensuing decline of the water level over time until it returned to equilibrium. Instantaneous water levels were recorded at intervals that varied from every 0.2 seconds at the beginning of the test to every 30 seconds at the end of the test. The decline in water level after removal of the slug from the well and the subsequent rise to equilibrium were also recorded on some wells.

For wells completed in the Columbia aquifer, slug-test data were analyzed by the Bouwer and Rice method (Bouwer and Rice, 1976; Bouwer, 1989), which is considered appropriate for unconfined conditions and can be applied to partially screened aquifers. Slug-test data from wells completed in the upper confined aquifer and the Nanjemoy-Marlboro confining unit were analyzed using a method described by Cooper, Bredehoeft, and Papadopulos (1967), which is considered appropriate for wells that are fully screened in confined aquifers. If available, data from slug-removal tests were used to obtain the hydraulic conductivities presented in this report; however, conductivities were calculated from both slug-addition and slug-removal tests to ensure that they differed by no more than one order of magnitude.

\section{Water-Quality Sampling and Analysis}

Water-quality samples were collected from the 28 wells, from 2 surface-water sites in Machodoc Creek, and from 1 surface-water site in Black Marsh (fig. 2) in July 1994. Field parameters and the concentrations of selected chemical constituents, including major ions, were determined for all water-quality samples. Water-quality data were used to assess the background geochemistry of ground water and surface water at the EEA, and to determine the major hydro- geochemical processes that affect ground-water quality at the EEA. Water-quality data are presented in Hammond and Bell (1995).

Prior to the collection of water-quality samples, all equipment was cleaned thoroughly with laboratory detergent, and rinsed using distilled water. The outside of the pump and Teflon tubing were rinsed using distilled water between sampling, and the entire system was flushed using distilled water after each day of sampling. Ground-water samples were collected by use of a stainless steel submersible pump with a Teflon discharge tube. Each well was purged of at least three well volumes of water prior to sampling, unless the well went dry in which case the water level was allowed to recover completely prior to sampling. Surface-water samples were collected by use of a weighted-bottle sampler and 2-L polyethylene bottle using the equal-width-increment method (Edwards and Glysson, 1988), and composited in a Teflon churn splitter.

Temperature, dissolved oxygen, specific conductance, $\mathrm{pH}$, and alkalinity were measured in the field. Temperature and dissolved oxygen were measured in wells and surface water after sampling by use of a YSI (model 54A) dissolved oxygen meter with cable and submersible stirrer. The dissolved oxygen meter was calibrated to air at least once per day. Specific conductance and $\mathrm{pH}$ were measured on unfiltered water samples by use of an Orion (model 122) specific conductance meter with glass conductivity cell and Orion (SA 250) pH meter with gel-filled $\mathrm{pH}$ electrode, respectively. The calibration of the specific conductance meter was checked each day using three solutions of known conductance. The $\mathrm{pH}$ meters were calibrated each day using two solutions of known $\mathrm{pH}$ values (usually pH 4 and 7). Alkalinities were determined by incremental titration of $100-\mathrm{mL}$ filtered water samples using sulfuric acid.

Water samples collected for dissolved inorganic analyses were filtered immediately after collection to minimize oxidation of any unstable and chemically reduced solutes and then placed in acid-rinsed bottles. The filtering was accomplished by use of a peristaltic pump with silicon tubing and a 142-mm-diameter filter-plate assembly with $0.45-\mu \mathrm{m}$ pore-size filter membrane. The filter membranes were flushed with $200 \mathrm{~mL}$ of American Society of Testing and Materials Type II water before filtration of the sample. Water samples collected for major cations and metals were acidified to $\mathrm{pH} 2$ using concentrated nitric acid. All 
equipment used for sampling dissolved organic carbon was first rinsed using carbon-free water; sample water was then passed through a $0.45-\mu \mathrm{m}$ silver filter and placed into clear glass bottles. All sample bottles were placed in sealed plastic bags, stored on ice, and shipped overnight in high-impact plastic ice chests to the laboratories.

Quality controls included duplicate samples, an equipment blank, and a carbon-free deionized water blank. Duplicate samples were collected at approximately 10 percent of the sampling sites, including one duplicate surface-water sample to determine the reproducibility of water-quality data. The equipment blank was collected by passing carbon-free deionized water through the pump and tubing.

All water-quality samples were sent to the USGS National Water Quality Laboratory in Arvada, Colo., for determination of inorganic constituents and organic carbon. Metals and major cations were measured by use of inductively coupled argon plasma spectroscopy. Chloride and fluoride were measured by a colorimetric method, and sulfate concentrations were determined by a turbidimetric method. Total dissolved solids were measured as residue-on-evaporation at $180^{\circ} \mathrm{C}$. The analytical methods are described in Wershaw and others (1987) and Fishman and Friedman (1989). Laboratory quality-assurance procedures are described in Friedman and Erdmann (1982) and Jones (1987).

\section{HYDROGEOLOGY OF THE SHALLOW AQUIFER SYSTEM}

The shallow aquifer system underlying the EEA, as defined in this report, comprises the uppermost $100 \mathrm{ft}$ of sediments, and has been divided into four hydrogeologic units: (1) the Columbia aquifer; (2) the upper confining unit; (3) the upper confined aquifer; and (4) the Nanjemoy-Marlboro confining unit (fig. 3). In some areas of the EEA, the upper confining unit and upper confined aquifer are missing and the Columbia aquifer lies directly on the NanjemoyMarlboro confining unit. Lithologic data and geophysical borehole logs collected for this study and the hydrogeologic assessment of the Mainside (Harlow and others, 1996) provided the primary basis for framework interpretation. Other sources of hydrogeologic data included outcrops along Machodoc Creek and the Potomac River, lithologic logs of a borehole at Little Ferry Landing, and lithologic and geophysical logs of a water-supply well at the EEA (unpublished data on file in the Virginia District office of the U.S. Geological Survey).

\section{Geology}

Several thousand feet of unconsolidated sedimentary deposits of the Coastal Plain Physiographic Province underlie the NSWCDL. These deposits consist of tabular bodies of interbedded sand, silt, and clay, and range in age from Cretaceous to Quaternary (Meng and Harsh, 1988). The stratigraphy and inferred depositional environments of the sediments that constitute the shallow aquifer system at the EEA are derived from previous investigations (Ward, 1985; Meng and Harsh, 1988; Mixon and others, 1989; Harlow and Bell, 1996) and from interpretations of lithologic and geophysical data collected for this investigation.

\section{Stratigraphy}

The basal geologic unit of the shallow aquifer system is the Nanjemoy Formation of Eocene age (fig. 3). The Nanjemoy Formation is divided formally into the lower Potapaco Member, which consists of glauconitic sandy clay; and the upper Woodstock Member, which consists of very glauconitic, micaceous silty sand. At the EEA, the Potapaco Member crops out at several locations along the shores of the Machodoc Creek and the Potomac River. The Potapaco Member can be recognized by its distinctive lithology (glauconitic silty fine sands) and the presence of abundant bivalve fossils, including Venericardia ascia and Macrocallista subimpressa (Ward, 1985).

The Nanjemoy Formation is unconformably overlain by deposits of Pleistocene age, which are divided, in this report, into two geologic units: undifferentiated Pleistocene deposits and the Tabb Formation of late Pleistocene age. The undifferentiated Pleistocene deposits consist of coarse-grained sand and pebbles that fine upward to interbedded fine- to medium-grained sand, clay, and peat, and then to clay that contains abundant wood fragments at the top of the unit. Pollen analysis of cores from this unit confirmed the age of this unit as Pleistocene, but it currently is unknown with which formally defined geologic formation these deposits correlate. Possibilities include the Shirley and Charles City Formations. 


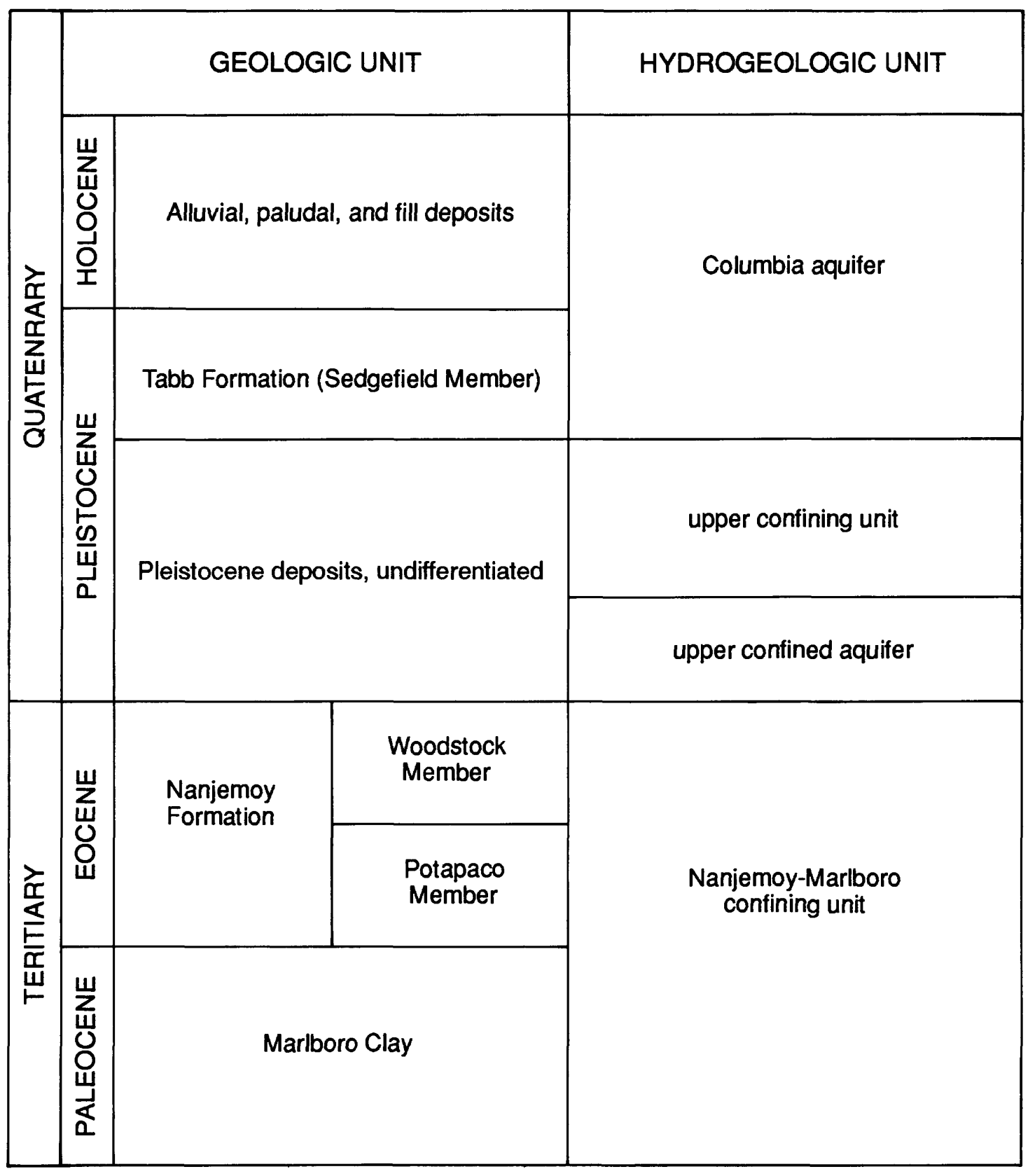

NOT TO SCALE

Figure 3. Schematic diagram of geologic and hydrogeologic units of the shallow aquifer system at the Explosive Experimental Area, Dahlgren, Virginia. 
The Charles City Formation has been mapped at the top of the Dahlgren scarp south of the eastem part of the EEA (Mixon and others, 1989).

The Sedgefield Member of the Tabb Formation overlies the undifferentiated Pleistocene deposits, and consists of fine- to coarse-grained sand and pebbles that fine upward into silt and clay. The Sedgefield Member of the Tabb Formation has been mapped as the surficial geologic unit across the entire EEA (Mixon and others, 1989); no deposits of the Lynnhaven or Poquoson Members of the Tabb Formation have been mapped at the study area. Uraniumseries age dating of corals from the Sedgefield Member have yielded an average age of 71,000 $\pm 7,000$ years before present (B.P.) (Mixon and others, 1989); however, basal sands may be as old as 100,000 years B.P. (R. Berquist, Virginia Division of Mineral Resources, oral commun., 1995). Organic-rich mud, sand, and peat of Holocene age are found in intertidal areas at the EEA.

\section{Depositional History}

Sediments of the Nanjemoy Formation were deposited in a protected marine shelf with water levels that ranged from 50 to $230 \mathrm{ft}$ (Meng and Harsh, 1988). During several Miocene, Pliocene, and Pleistocene marine transgressions, additional sediments were deposited over the study area that have been subsequently removed by erosion during the late Pleistocene. For example, Miocene and Pliocene sediments of the Chesapeake Group crop out at the face of the Dahlgren scarp, south and west of the EEA, however, they are no. longer present at the EEA.

During a Pleistocene glacial period, fluvial erosion incised deep (greater than $80 \mathrm{ft}$ ) paleochannels into the Nanjemoy Formation, which filled with the undifferentiated Pleistocene sediments during the subsequent interglacial period as sea level rose. These sediments were deposited in a high-energy fluvial environment that gradually changed to a low-energy estuarine-paludal (marsh) environment during the course of the transgression. The undifferentiated Pleistocene sediments may be contemporaneous with the Charles City Formation that has been mapped at the top of the Dahlgren scarp (Mixon and others, 1989). Alternatively, these sediments may correlate with the Shirley Formation, which is one of the most extensive Pleistocene units in the Virginia Coastal Plain Physiographic Province.
The Sedgefield Member of the Tabb Formation was deposited in a fluvial-estuarine setting during a later Pleistocene marine transgression. Sedgefield depositional environments at the EEA range vertically and laterally from high-energy fluvial environments to low-energy floodplain and estuarine environments. Maximum sea level during the deposition of the Sedgefield Member was approximately $30 \mathrm{ft}$ above present sea level, and thus the Sedgefield member was not deposited on top of the Dahlgren scarp.

The Holocene Epoch began approximately 10,000 years ago as sea level began to rise following the Wisconsinan glacial period. Low areas at the EEA, such as Black Marsh and unnamed tributaries to Machodoc Creek and the Potomac River, were inundated during the Holocene, resulting in the deposition of paludal (swamp and marsh) mud, sand, and peat.

\section{Physical Properties of Hydrogeologic Units}

The following sections describe the lithology, hydraulic characteristics, extent, and thickness of hydrogeologic units beneath the EEA. The interpreted hydrogeologic framework is illustrated by use of maps and hydrogeologic sections. Hydrogeologic data collected for this investigation are published in Hammond and Bell (1995).

\section{Columbia Aquifer}

The Columbia aquifer is present across the entire EEA, but it has highly variable physical properties that correspond to the range of depositional environments in which it was formed. The Columbia aquifer consists of sand, silt, and clay, and a pebble lag deposit present at the base of the aquifer in most locations. The Columbia aquifer correlates with the Sedgefield Member of the Tabb Formation and Holocene paludal deposits (fig. 3), however, it also contains artificial fill material at some locations. The finingupward nature of the Tabb Formation causes the aquifer generally to have the most permeable sediments at its base, and the least permeable sediments near land surface. At any one location, however, multiple finingupward sequences may be present in the aquifer. Rates and directions of flow in the Columbia aquifer are affected strongly by local lithologic heterogeneities, such as thin layers of clay or coarse-grained paleochannel deposits. 
The depth from land surface to the top of the first confining unit represents the maximum potential thickness of the Columbia aquifer; this thickness varies from less than $8 \mathrm{ft}$ at well EEA-S4 to approximately $34 \mathrm{ft}$ at well EEA-S13 (fig. 4). A hydrogeologic map of the altitude of the bottom of the Columbia aquifer (fig. 4) illustrates the erosional surface formed prior to deposition of the Tabb Formation. The actual saturated thickness of the Columbia aquifer varies seasonally as water levels rise and fall. In general, the depth to the first confining unit is greatest in the southern part of the EEA, where Pleistocene streams have eroded older material and deposited thick beds of sand and pebbles. These paleochannel deposits were noted during construction of wells EEAS3, S11, S12, S13, and S15, where the depth to the first confining unit exceeds $20 \mathrm{ft}$. Coarse-grained deposits also were noted during construction of wells EEA-S6 and EEA-S8, suggesting that paleochannels also underlie the northem part of the EEA.

The depth to the first confining unit is generally less than $15 \mathrm{ft}$ in the central area of the EEA, as indicated by borehole logs from wells EEA-S2, S4, S5, S7, S9, S10, S16, S17, S18, and S19. This central area of the EEA roughly corresponds to an east-west trending band, where the upper confining unit is missing and the Columbia aquifer directly overlies the Nanjemoy-Marlboro confining unit. In such areas, the contact between the Columbia aquifer and the Nanjemoy-Marlboro confining unit lies above sea level and can be viewed in outcrops along the Machodoc Creek and the Potomac River. North and south of this area, the Columbia aquifer overlies the upper confining unit.

The variable lithology of the Columbia aquifer results in a wide range of hydraulic properties. Horizontal hydraulic conductivities in the Columbia aquifer, calculated from slug tests of 18 wells, ranged from $0.10 \mathrm{ft} / \mathrm{d}$ (well EEA-S10) to $21 \mathrm{ft} / \mathrm{d}$ (well EEA-S17), with a median value of $1.4 \mathrm{ft} / \mathrm{d}$ (table 1 , fig. 5). The base of the Columbia aquifer, where wells completed for this study were screened, contains the coarsestgrained deposits of the aquifer; therefore, horizontal hydraulic conductivities calculated from slug tests represent some of the most permeable sediments of the aquifer.

In the center of the EEA, at wells EEA-S4, S9, S10, and S18, horizontal hydraulic conductivities generally are less than $1 \mathrm{ft} / \mathrm{d}$; whereas in the northern and southern areas of the EEA, horizontal hydraulic conductivities generally are greater than $1 \mathrm{ft} / \mathrm{d}$. This pattern does not hold everywhere, as indicated by low horizontal hydraulic conductivities at wells EEA-S1 and $S 11$ ( 0.20 and $0.19 \mathrm{ft} / \mathrm{d}$, respectively). The Columbia aquifer, however, is thicker in the northern and southern parts of the EEA than in the central area, and transmissivity would be greater in those areas even where the horizontal hydraulic conductivity is not significantly higher.

Vertical hydraulic conductivities in the Columbia aquifer, measured by falling-head permeameter tests of seven Shelby tube cores, ranged from a minimum of $0.0023 \mathrm{ft} / \mathrm{d}$ in a sandy clay (well EEA-S3) to a maximum of $4.3 \mathrm{ft} / \mathrm{d}$ in a sand (well EEA-M2), with a median value of $0.14 \mathrm{ft} / \mathrm{d}$ (fig. 5). Shelby tube cores cannot penetrate very pebbly sediments or very hard clays; therefore, vertical hydraulic conductivities obtained from Shelby tube cores do not represent the upper and lower extreme vertical permeabilities for the Columbia aquifer.

At some locations, the Columbia aquifer contains thick deposits of clay that can significantly impede downward movement of water. A highly plastic, stiff, mottled clay, for example, underlies much of the northern area of the EEA (EEA-S6, S7, S8, S17, $\mathrm{S} 18$, and $\mathrm{S} 20$ ). This clay lies at elevations ranging from 3 to $17 \mathrm{ft}$ above sea level, and varies in thickness from about $0.2 \mathrm{ft}$ at well EEA-S7 to more than $10 \mathrm{ft}$ at well EEA-S20. Because the clay pinches out, or was eroded to the south, it was not observed at wells EEAS5, S9, or S16.

\section{Upper Confining Unit}

The upper confining unit consists of plastic clay, silty clay, and clayey sand that is grey in color and contains abundant organic material, including wood fragments. This unit is overlain by the Columbia aquifer and has a gradational contact with the underlying upper confined aquifer. In some areas, the upper confining unit may directly overlie the NanjemoyMarlboro confining unit. The upper confining unit correlates with the upper, fine-grained, undifferentiated Pleistocene deposits (fig. 3).

The upper confining unit is not present across the entire EEA; either it was not deposited or it was eroded from an east-west trending band across the center of the EEA. In this area, the Columbia aquifer directly overlies the Nanjemoy-Marlboro confining unit, as illustrated in hydrogeologic section $A-A^{\prime}$ (fig. 6). The altitude of the top of the upper confining 


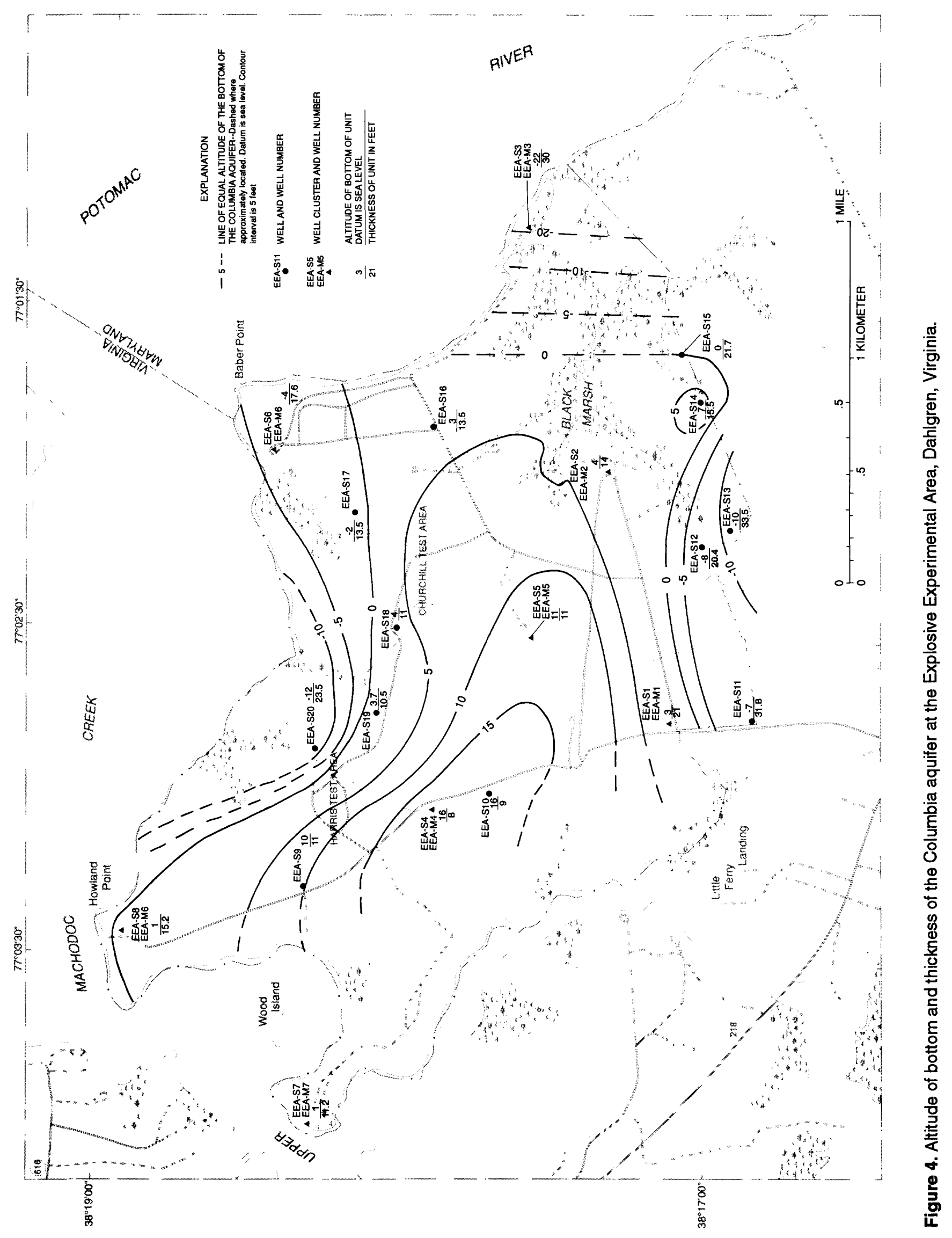


Table 1. Horizontal hydraulic conductivities determined from slug tests at the Explosive Experimental Area, Dahlgren, Virginia

[for locations of wells, see figure 2; slug-test data from wells completed in the Columbia aquifer were analyzed by the Bouwer and Rice method (Bouwer and Rice, 1976; Bouwer, 1989); slug-test data from wells completed in the upper confined aquifer and the Nanjemoy-Marlboro confining unit were analyzed using a method described by Cooper, Bredehoeft, and Papadopulos (1967)]

\begin{tabular}{|c|c|c|c|}
\hline Well number & Hydrogeologlc unlt & Type of slug test & $\begin{array}{l}\text { Horizontal hydraulic } \\
\text { conductivity } \\
\text { (feet per day) }\end{array}$ \\
\hline EEA-S1 & Columbia aquifer & removal & 0.20 \\
\hline EEA-\$3 & Columbia aquifer & removal & 12 \\
\hline EEA-S4 & Columbia aquifer & addition & .63 \\
\hline EEA-S6 & Columbia aquifer & removal & 6.8 \\
\hline EEA-\$7 & Columbia aquifer & addition & 1.8 \\
\hline EEA-S8 & Columbia aquifer & removal & 1.5 \\
\hline EEA-\$9 & Columbia aquifer & addition & .58 \\
\hline EEA-S10 & Columbia aquifer & addition & .10 \\
\hline EEA-S11 & Columbia aquifer & addition & .19 \\
\hline EEA-S12 & Columbia aquifer & removal & 1.4 \\
\hline EEA-S13 & Columbia aquifer & addition & 5.7 \\
\hline EEA-S14 & Columbia aquifer & addition & 9.5 \\
\hline EEA-S15 & Columbia aquifer & removal & 8.7 \\
\hline EEA-S16 & Columbia aquifer & removal & 1.6 \\
\hline EEA-\$17 & Columbia aquifer & removal & 21 \\
\hline EEA-S18 & Columbia aquifer & addition & .63 \\
\hline EEA-S19 & Columbia aquifer & addition & 1.2 \\
\hline EEA-S20 & Columbia aquifer & removal & 1.0 \\
\hline EEA-M1 & upper confined aquifer & removal & 1.1 \\
\hline EEA-M2 & Nanjemoy-Marlboro confining unit & addition & .0086 \\
\hline EEA-M3 & upper confined aquifer & removal & 3.3 \\
\hline EEA-M4 & Nanjemoy-Marlboro confining unit & addition & .043 \\
\hline EEA-M5 & Nanjemoy-Marlboro confining unit & removal & .026 \\
\hline EEA-M6 & upper confined aquifer & removal & 5.1 \\
\hline EEA-M7 & Nanjemoy-Marlboro confining unit & removal & .0032 \\
\hline EEA-M8 & upper confined aquifer & removal & 23 \\
\hline
\end{tabular}



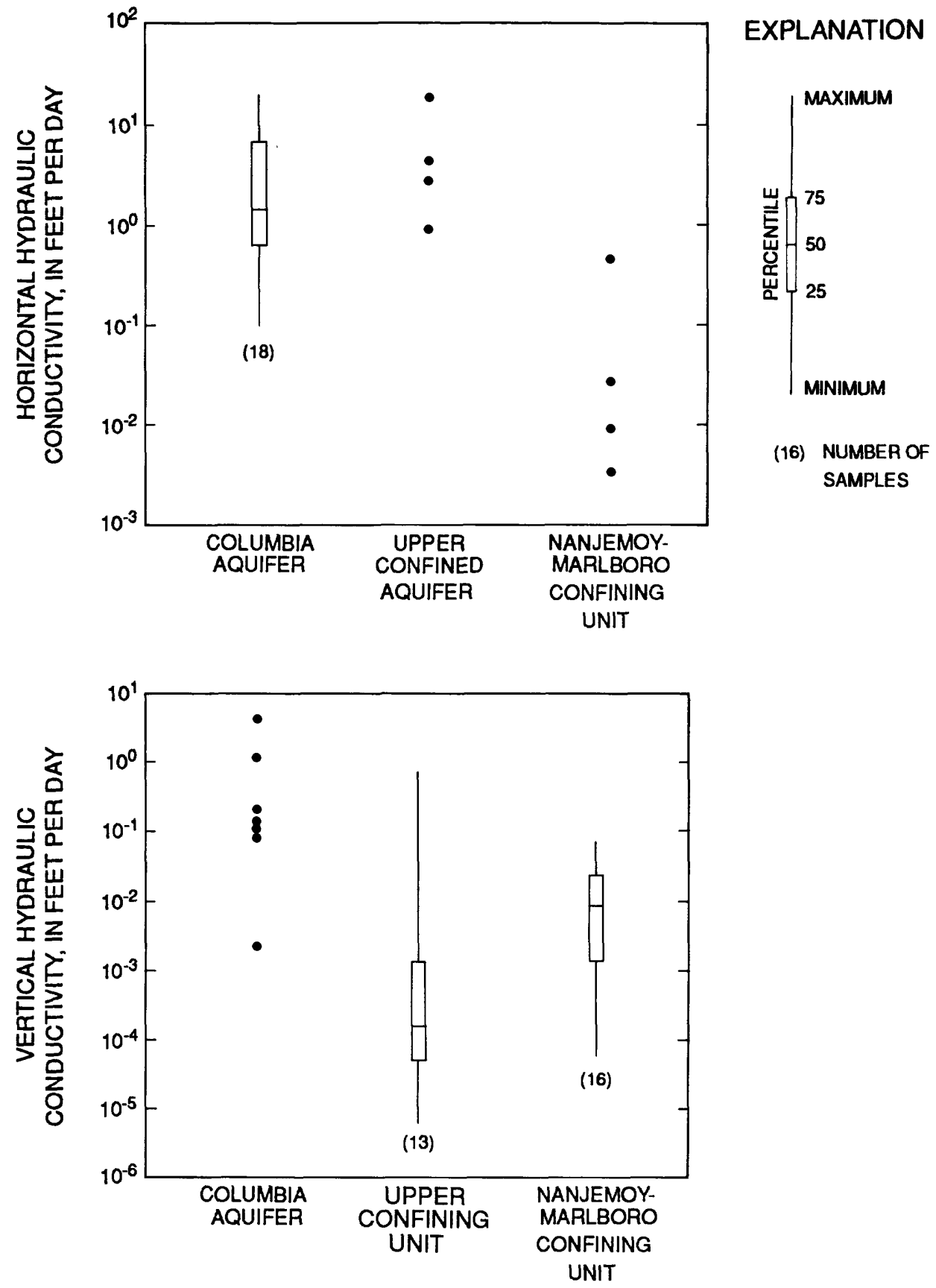

Figure 5. Distribution of horizontal and vertical hydraulic conductivity of hydrogeologic units at the Explosive Experimental Area, Dahlgren, Virginia. (Horizontal hydraulic conductivity was calculated from slug tests; vertical hydraulic conductivity was measured from falling-head permeameter tests of Shelby tube samples.) 
unit ranges from $21.8 \mathrm{ft}$ below sea level (well EEAM3) to approximately $13 \mathrm{ft}$ above sea level (well 54Q12) (fig. 7), and reaches about $21.0 \mathrm{ft}$ above sea level just outside the EEA at Little Ferry Landing (fig. 7) (unpublished data on file at the Virginia District office of the U.S. Geological Survey).

Pleistocene streams eroded a high-relief surface into the top of the upper confining unit. Correspondingly, the altitude of the top of the upper confining unit is lowest where the Columbia aquifer has the coarsest, most permeable sediments, such as at well EEA-S3 and EEA-S6. The upper confining unit at the EEA ranges in thickness from about $18 \mathrm{ft}$ (well 54Q12) to about $51 \mathrm{ft}$ (well EEA-S6) (fig. 7) and reaches $61 \mathrm{ft}$ at Little Ferry Landing (unpublished data on file at the Virginia District office of the U.S. Geological Survey). The unit is absent in the center of the study area.

The upper confining unit has the lowest permeability values in the shallow aquifer system (fig. 5), as indicated by falling-head permeameter test of 13 Shelby tube cores (Hammond and Bell, 1995). Vertical hydraulic conductivities ranged from $6.5 \times 10^{-6} \mathrm{ft} / \mathrm{d}$ (well EEA-M8) to $0.71 \mathrm{ft} / \mathrm{d}$ (EEA-M6), with a median value of $2.0 \times 10^{-4} \mathrm{ft} / \mathrm{d}$ (fig. 5).

\section{Upper Confined Aquifer}

The upper confined aquifer consists of interbedded sand and clay grading downward into sand and pebbles. The sand is typically glauconitic, and the entire aquifer contains abundant organic material, including wood fragments and tree stumps. The upper confined aquifer has a gradational contact with the overlying upper confining unit, and unconformably overlies the Nanjemoy-Marlboro confining unit. Geologically, this unit correlates with the lower, coarsegrained part of the undifferentiated Pleistocene deposits (fig. 3). At some locations, notably well EEA-S2, fine sands of the Nanjemoy Formation also are included as part of the upper confined aquifer.

The upper confined aquifer was deposited in paleochannels and, thus, is not present across the entire EEA. As expected, the upper confined aquifer has a similar areal distribution to the upper confining unit; the aquifer is present in the northern and southern parts of the EEA, but it was not deposited over an eastwest trending band across the center of the study area (fig. 8). The altitude of the top of the aquifer decreases to the north and to the south of this area, ranging from $17 \mathrm{ft}$ below sea level (well EEA-M2) to $57 \mathrm{ft}$ below sea level (well EEA-M3) (fig. 8). The observed thick-

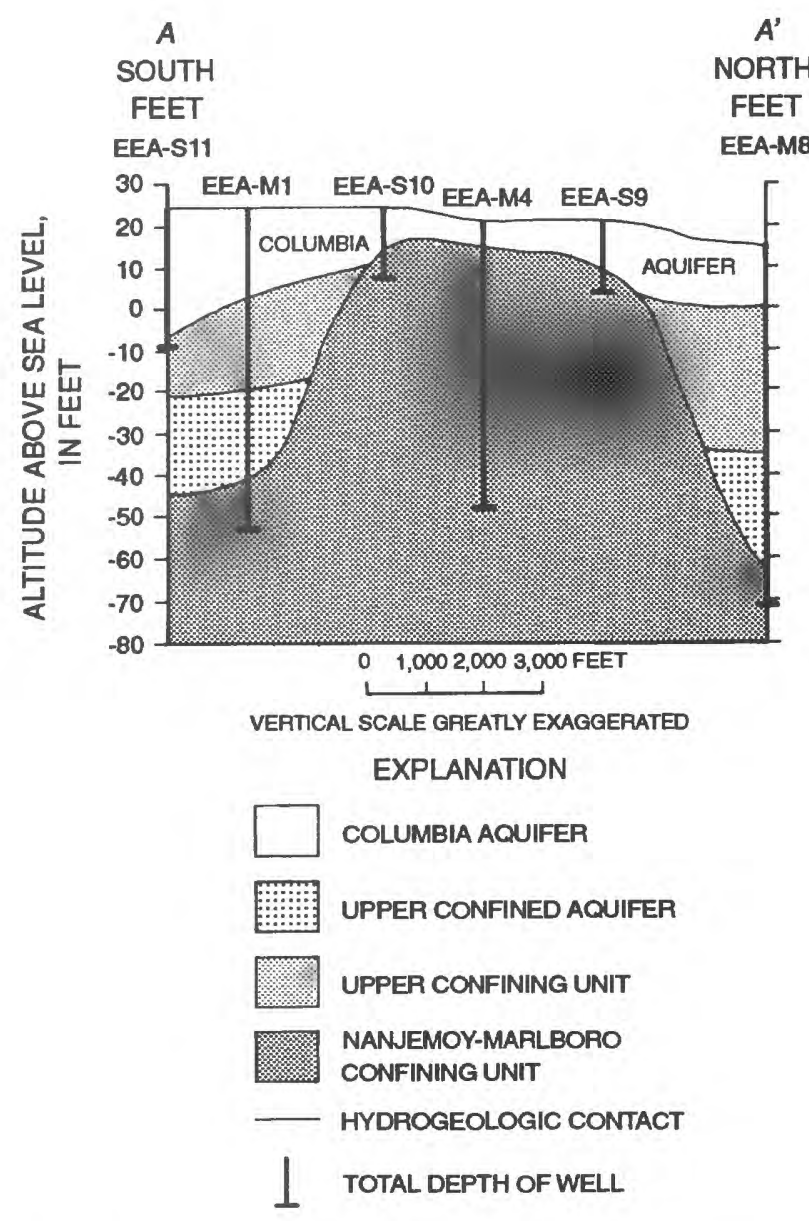

Figure 6. Hydrogeologic section $A-A^{\prime}$ at the Explosive Experimental Area, Dahlgren, Virginia. (Line of section shown in figure 2.)

ness of the upper confined aquifer varies from about $11 \mathrm{ft}$ (well EEA-M2) to about $33 \mathrm{ft}$ (well EEA-M3) (fig. 8). The base of the upper confined aquifer, like that of many fluvial deposits, exhibits high relief, ranging from $90 \mathrm{ft}$ below sea level (well EEA-S3) to about $28 \mathrm{ft}$ below sea level (well EEA-M2). The upper confined aquifer is the most permeable unit in the shallow aquifer system (fig. 5). Horizontal hydraulic conductivities from 4 slug tests range from $1.1 \mathrm{ft} / \mathrm{d}$ (well EEA-M1) to $23 \mathrm{ft} / \mathrm{d}$ (well EEA-M8) (table 1).

\section{Nanjemoy-Marlboro Confining Unit}

The Nanjemoy-Marlboro confining unit consists of greenish-black, silty, fine-grained sand and sandy clay. This unit is very glauconitic and contains abundant bivalve fossils. Geologically, the NanjemoyMarlboro confining unit correlates with the Nanjemoy Formation of Eocene age and the Marlboro Clay of 


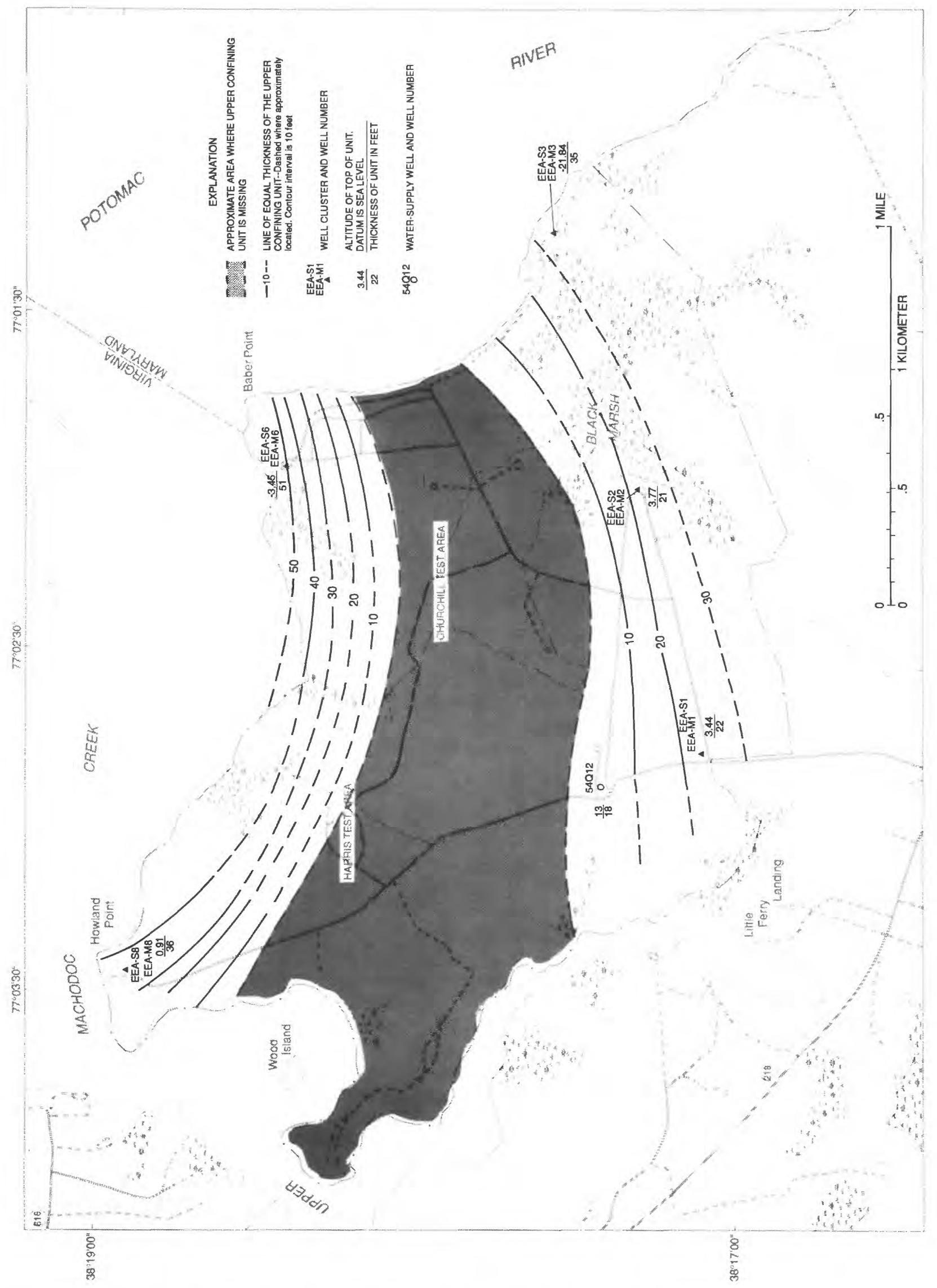

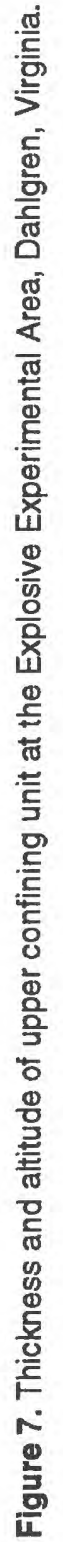




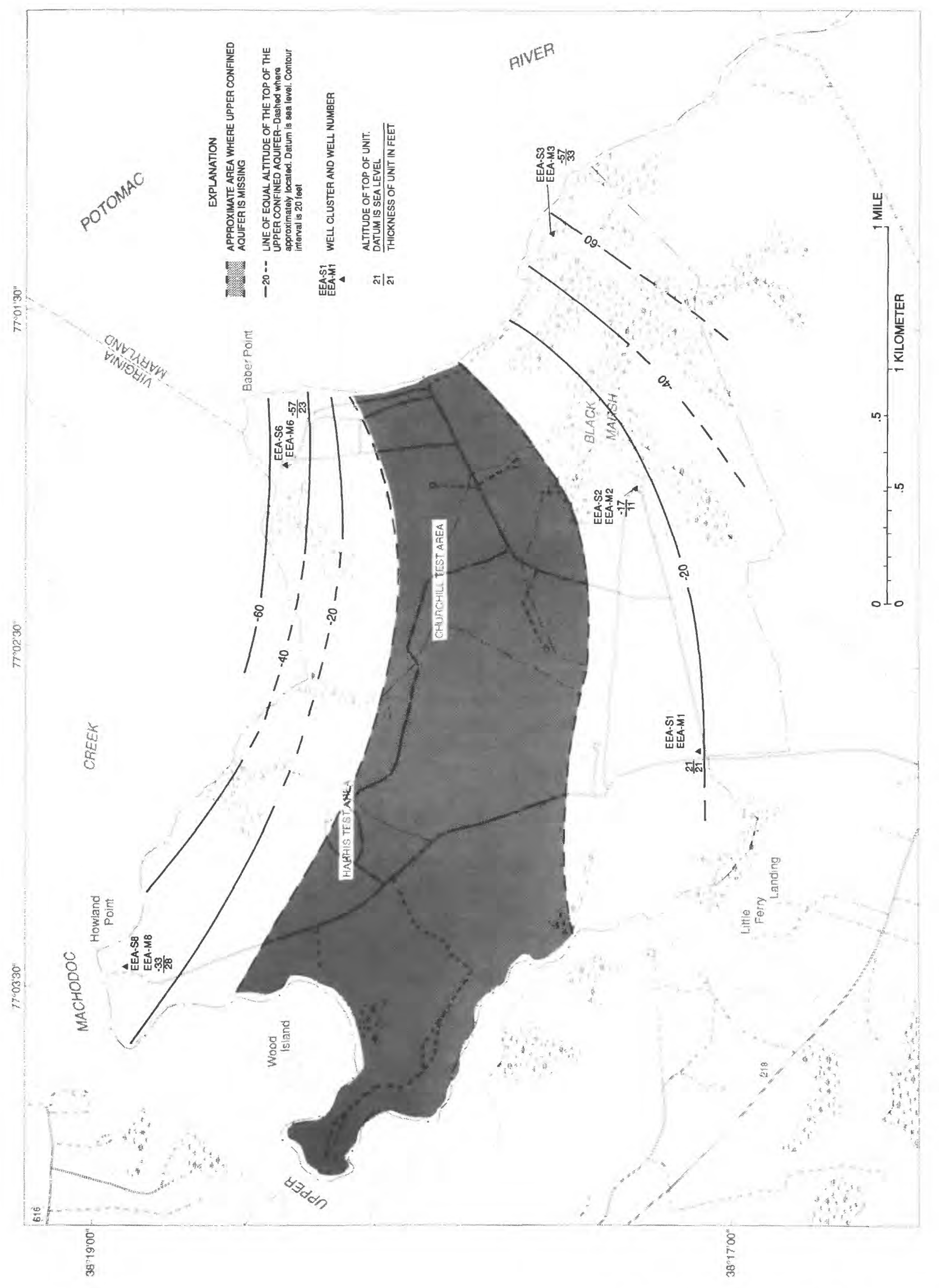

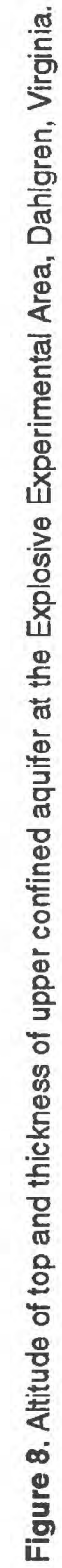


Paleocene age, although wells drilled for this study did not reach the latter unit. Locally, glauconitic silty sands from the Nanjemoy Formation that were reworked during the Pleistocene epoch are included in the Nanjemoy-Marlboro confining unit. These Pleistocene sediments are lithologically very similar to the Nanjemoy Formation but contain Pleistocene pollen and lack Eocene bivalves.

Pleistocene erosion carved a surface of high (greater than $100 \mathrm{ft}$ ) relief on the top of the NanjemoyMarlboro confining unit (figs. 6, 9). In the northern and southern areas of the EEA, fluvial erosion incised Nanjemoy-Marlboro deposits to a maximum depth of $90 \mathrm{ft}$ below sea level (well EEA-M3). An east-west trending band across the center of the EEA, however, was a paleointerfluve; in this area the top of the Nanjemoy-Marlboro confining unit lies above sea level and can be seen as outcrop along the shores of the Machodoc Creek and the Potomac River.

The Nanjemoy-Marlboro confining unit is more permeable than the upper confining unit (fig. 5). Horizontal hydraulic conductivities from 4 slug tests ranged from $3.2 \times 10^{-3} \mathrm{ft} / \mathrm{d}$ (well EEA-M7) to $4.3 \times 10^{-2}$ $\mathrm{ft} / \mathrm{d}$ (well EEA-M4) (table 1). Vertical hydraulic conductivities from falling-head permeameter tests of 16 Shelby tube cores ranged from $5.9 \times 10^{-5} \mathrm{ft} / \mathrm{d}$ to $7.1 \times 10^{-2} \mathrm{ft} / \mathrm{d}$, with a median value of $8.8 \times 10^{-3} \mathrm{ft} / \mathrm{d}$ (fig. 5).

\section{Hydrologic Characteristics of Aquifers}

Ground-water recharge, horizontal flow, and discharge pathways for the Columbia aquifer and the upper confined aquifer were interpreted from hydrogeologic data. Contour maps were drawn to illustrate the hydraulic head distribution of both aquifers during March and December 1994, which represent highwater and low-water conditions, respectively. Interpreted directions of ground-water flow are orthogonal to the contours of hydraulic head. Water-level data from the Nanjemoy-Marlboro confining unit were used to interpret the hydraulic connection of this unit with the two aquifers. Hydrographs were constructed to illustrate the responses of wells to precipitation, evapotranspiration, and tides.

\section{Columbia aquifer}

Hydraulic heads in the Columbia aquifer fluctuate as much as $10 \mathrm{ft}$ annually in response to changing rates of precipitation and evapotranspiration (figs. 10 and 11). The highest water levels were measured in the center of the EEA, where land-surface elevations exceed $20 \mathrm{ft}$ (wells EEA-S1, S4, S5, S9, S10, and S11). Water levels decrease toward major surfacewater drainages, such as Machodoc Creek, Black Marsh, and the Potomac River.

During high-water conditions, water levels in the Columbia aquifer are within $2 \mathrm{ft}$ of land surface across most of the EEA, and sometimes water levels rise above land surface, forming ponds in flat, poorly drained areas, such as at wells EEA-S4, S5, S9, S10, $\mathrm{S} 16, \mathrm{~S} 19$, and S20. In areas of high relief and sandy Columbia sediments, such as along the southern fence (wells EEA-S12, S13, S14, and S15), the water table usually remains $4 \mathrm{ft}$ or more beneath land surface. During low-water conditions, water levels approach or fall below sea level in wells EEA-S3 and S7, which lie very close to major surface-water bodies, and also in well EEA-S15, which drains rapidly because of high relief and permeable Columbia sediments.

\section{Recharge}

The Columbia aquifer is recharged directly by precipitation across most of the EEA. Water levels in most of the wells in the Columbia aquifer rise significantly and quickly after precipitation events (fig. 12), indicating a direct connection to the surface. Locally, water in the Columbia aquifer may be perched on top of clay layers or semi-confined beneath them. In particular, the plastic clay that lies beneath much of the northern area of the EEA could significantly impede vertical movement of ground water. Hydrographs at well clusters 4,5 , and 7 (fig. 13) indicate that during parts of the year there is an upward gradient between the Columbia aquifer and the underlying NanjemoyMarlboro confining unit, especially at well cluster 5 . In the Churchill Test Area, and possibly other areas, upward hydraulic gradients indicate that the Columbia aquifer can receive recharge from the underlying Nanjemoy-Marlboro confining unit.

Water-level maps indicate that the Columbia aquifer at the EEA is not significantly recharged from areas outside the EEA, with the exception of some areas along the southem boundary. Ground water flowing beneath the EEA from the south tends to discharge to Black Marsh, its tributaries, and a small tributary of Machodoc Creek before reaching the center of the study area. At wells located south of Black Marsh, (EEA-S13, S14, and S15) hydraulic heads are 


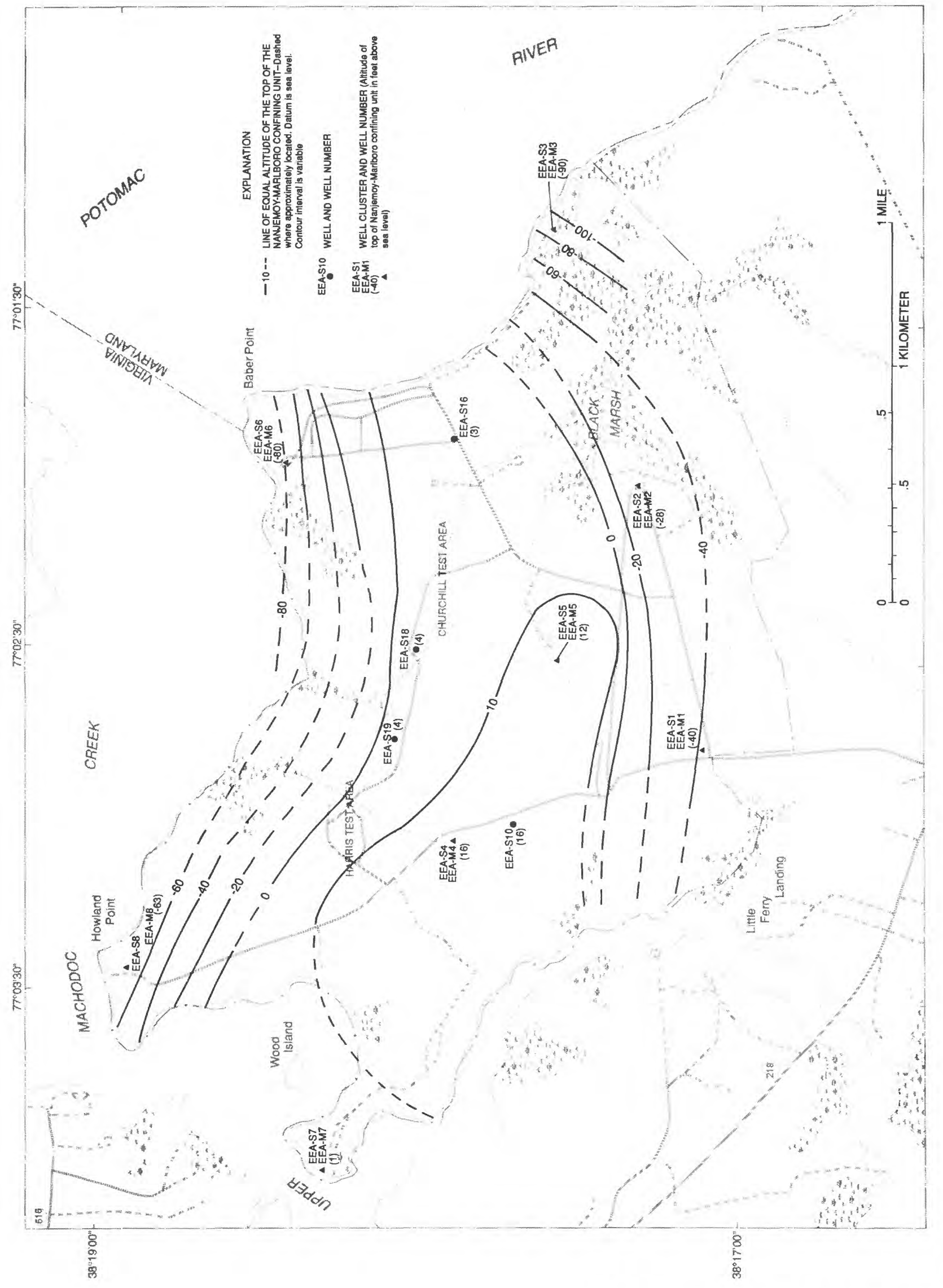

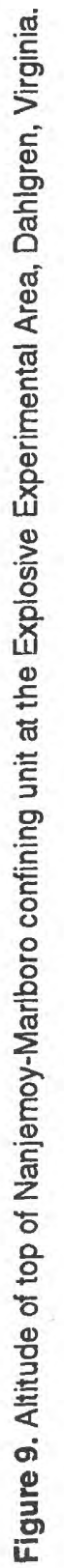




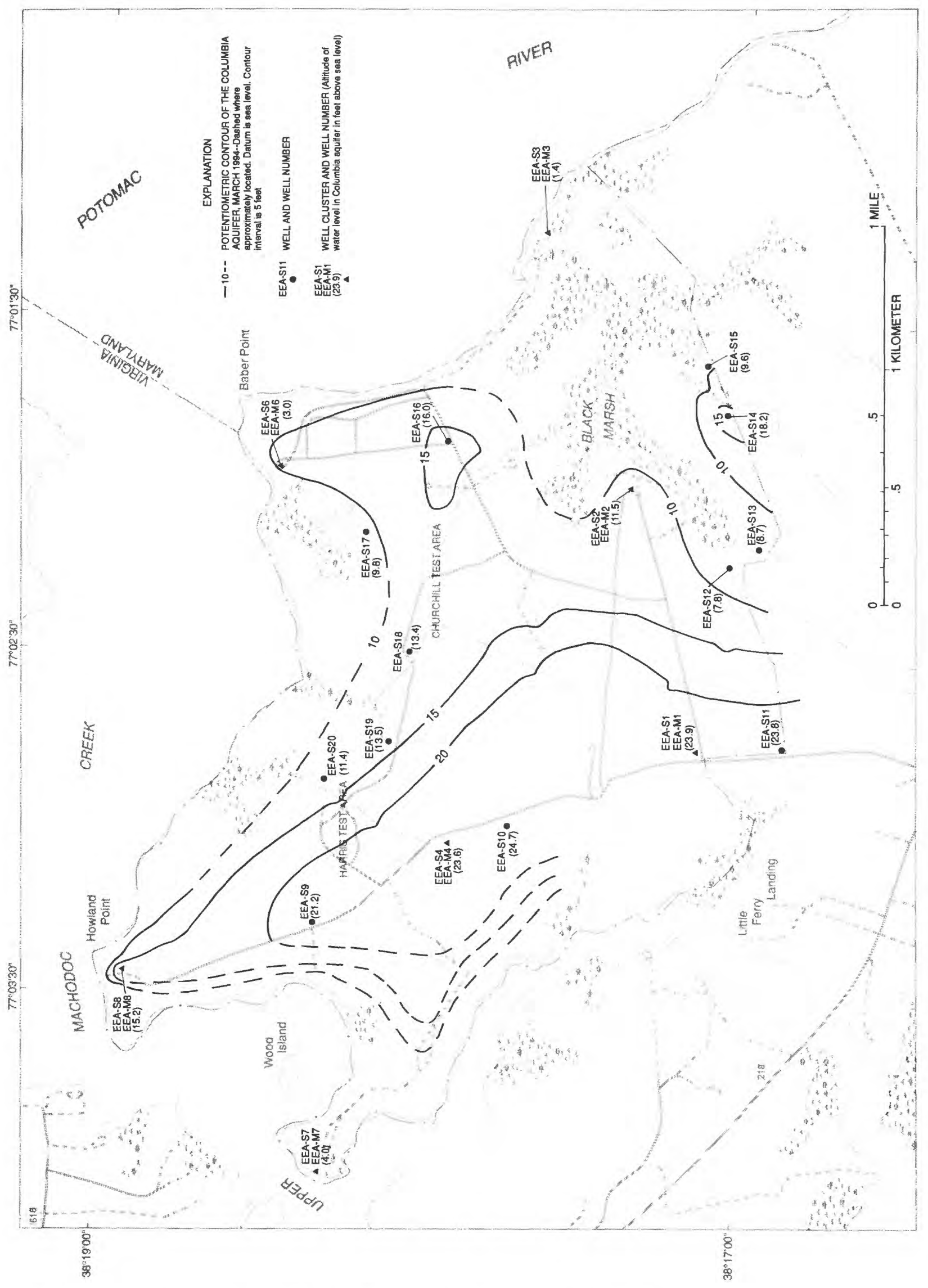

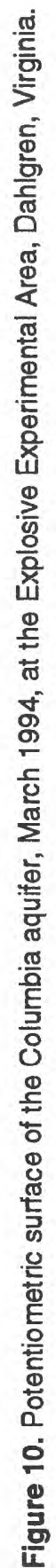




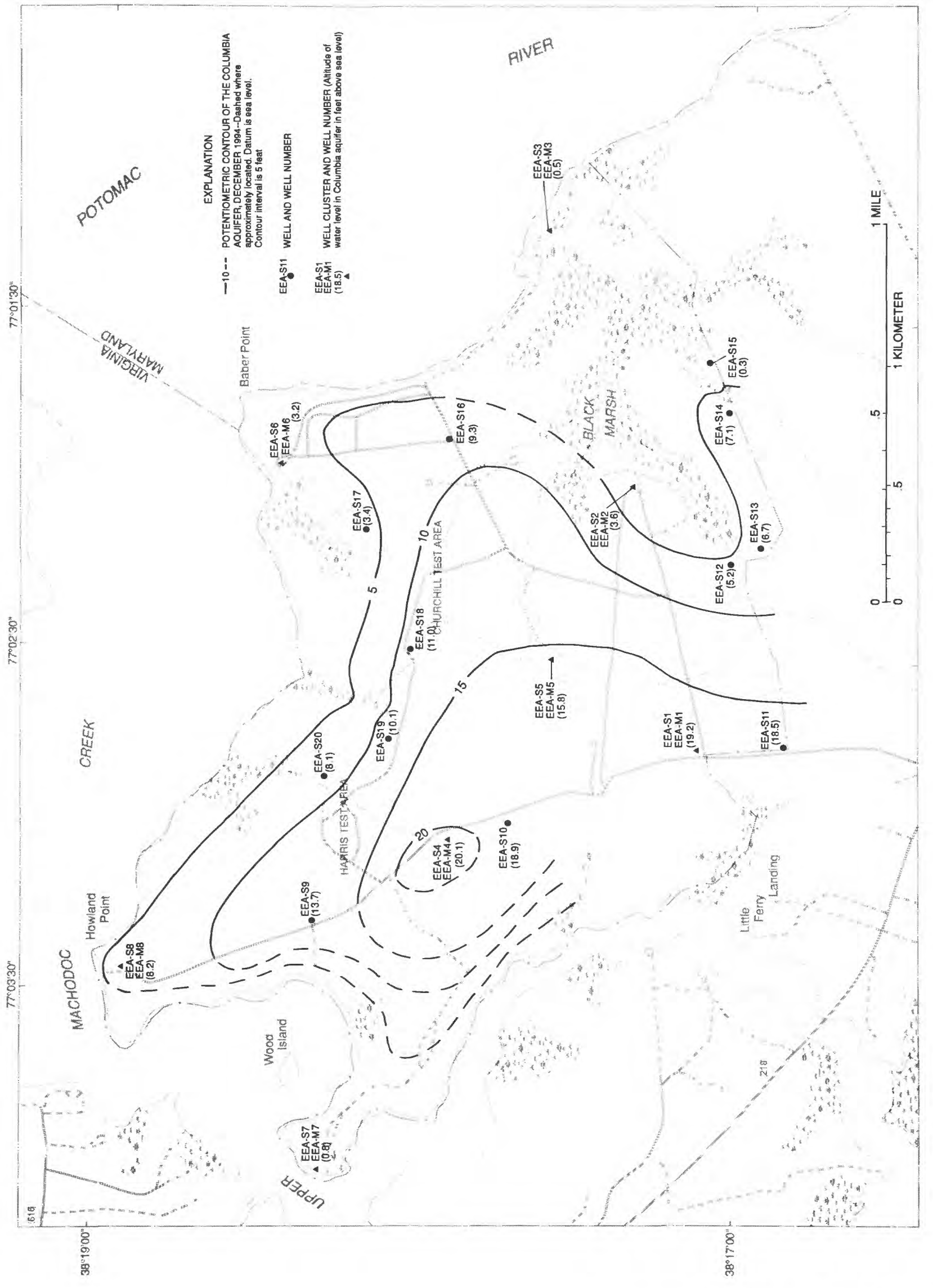

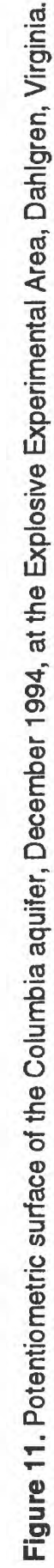




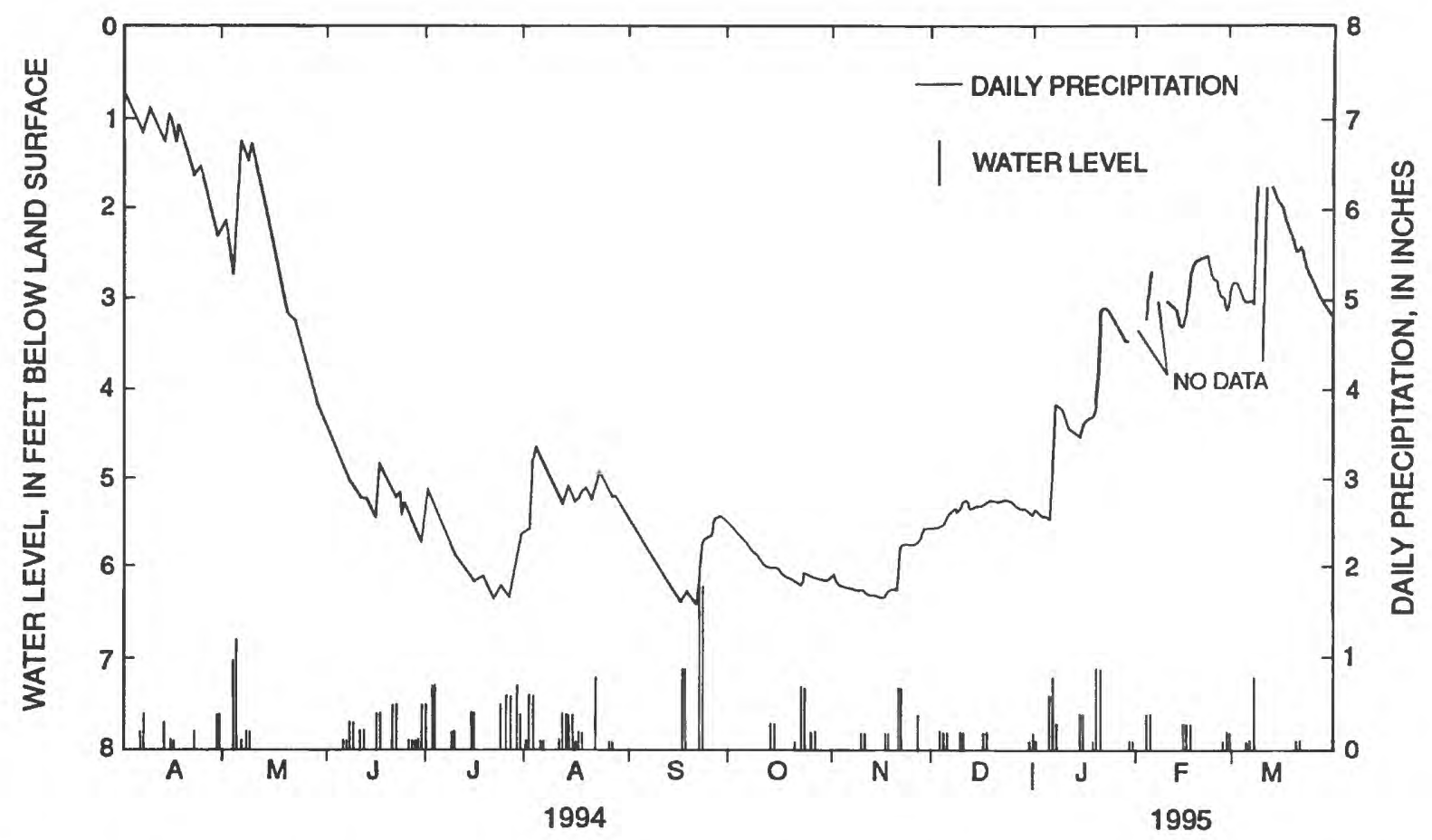

Figure 12. Maximum daily water level in the Columbia aquifer for well EEA-S1 and precipitation data, April 1994 through March 1995, at the Explosive Experimental Area, Dahlgren, Virginia.

significantly higher than those at nearby wells north of Black Marsh because ground water was recharged at higher elevations on the Dahlgren scarp or the upland terrace. For example, despite the close proximity of wells EEA-S12 and S13 (fig. 2), hydraulic head at well EEA-S13 is significantly higher than at well EEA-S12 (fig. 14) because these wells are located on opposite sides of a tributary to Black Marsh.

At well EEA-S3, the Columbia aquifer has a direct hydraulic connection with the Potomac River, as indicated by tidal oscillations in ground-water level and by water quality. The connection is enhanced by very permeable Columbia aquifer sediments, and isolation of the Columbia aquifer from upland areas. Well EEA-S3 is located on a small area of land surrounded on all sides by surface water (fig. 2), and thus shallow ground water is recharged only by direct precipitation and surface water.

\section{Horizontal Flow}

The water table is shallow and subparallel to land surface (figs. 10, 11). Water in the Columbia aquifer generally flows from topographically high areas beneath the western and central EEA toward topographically low areas, such as the Potomac River,
Machodoc Creek, Black Marsh, and unnamed tributaries of these surface-water bodies, as well as to drainage ditches and swales.

The horizontal hydraulic gradient is greater in the western third of the EEA than the eastern part because of the steep land-surface slope along the shore of Machodoc Creek upstream of Howland Point. The average horizontal hydraulic gradient across the entire study area is approximately 0.01 . Using an estimated aquifer porosity of 0.30 and a range in horizontal hydraulic conductivity of 0.10 to $21 \mathrm{ft} / \mathrm{d}$ (table 1), linear rates of ground-water flow in the Columbia aquifer are estimated to range from about 0.003 to $0.70 \mathrm{ft} / \mathrm{d}$ or about 1 to $300 \mathrm{ft} /$ year on average. These low rates of flow are expected for an area such as the EEA that generally has flat topography and relatively finegrained sediments. Rates of ground-water flow beneath topographically flat areas are less than the average, whereas flow rates beneath steep areas, such as near discharge areas, are greater than the average.

\section{Discharge}

Ground-water discharges from the Columbia aquifer by: (1) evapotranspiration, (2) springs and seeps, and (3) downward leakage to the Nanjemoy- 

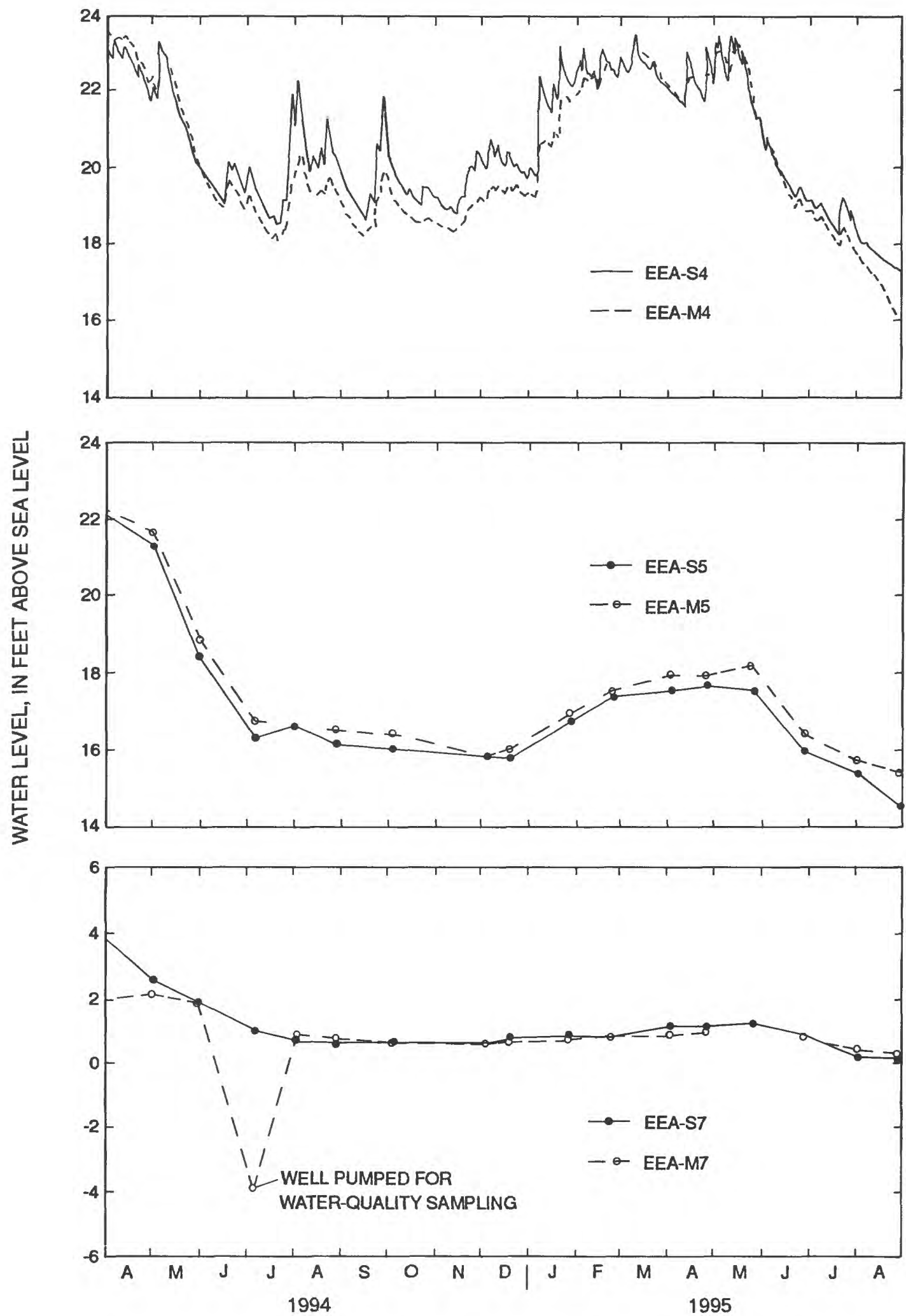

Figure 13. Maximum daily water level in the Columbia aquifer for well cluster 4 and synoptic waterlevel measurements for well clusters 5 and 7, April 1994 through April 1995, at the Explosive Experimental Area, Dahlgren, Virginia. 


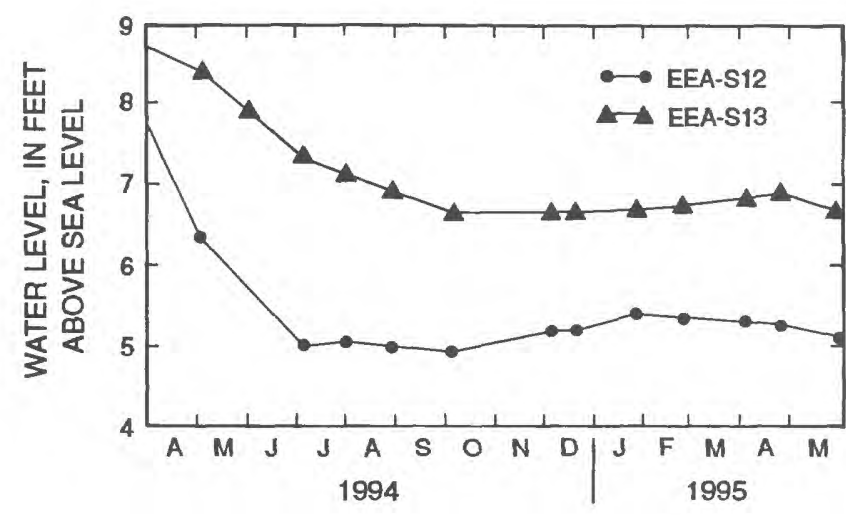

Figure 14. Maximum daily water levels in the Columbia aquifer for wells EEA-S12 and EEA-S13, April 1994 through March 1995, at the Explosive Experimental Area, Dahlgren, Virginia.

Marlboro confining unit. The water table lies within $10 \mathrm{ft}$ of land surface across most of the EEA, and ground water can evaporate directly to the atmosphere or can be taken up by plant roots. Evapotranspiration is most dramatic in forested areas, such as near well

EEA-S1, where it causes a marked diurnal fluctuation in water level from late May until early October

(fig. 15). Evapotranspiration is a major ground-waterdischarge pathway in flat, forested areas of the EEA. Evapotranspiration also occurs in the wetland areas fringing surface-water bodies, such as Black Marsh and Machodoc Creek, and their tributaries, which receive ground water from the upland areas of the EEA.

Erosion by the Machodoc Creek and the Potomac River has resulted in low (less than $30 \mathrm{ft}$ ) bluffs along the shoreline of the EEA. At these locations, ground water can discharge from springs and seeps as it flows along the top of the Nanjemoy-Marlboro confining unit, upper confining unit, or clay beds in the Columbia aquifer. A spring was observed discharging ground water to Machodoc Creek near well cluster 7 during October 1993, but such springs probably flow only during very wet periods. At other times, ground water discharges by evaporation from the seepage face of the bluff. Ground water also likely discharges from the Columbia aquifer directly to surface water by way of submarine seeps and springs.

\section{Hydraulic Connection with Nanjemoy-Marlboro Confining Unit}

In some areas where the Columbia aquifer directly overlies the Nanjemoy-Marlboro confining unit, there is an exchange of water between the two units. Hydraulic properties of the units are similar in areas where the Columbia aquifer consists of silty sand and finer material; for example, only about one order-of-magnitude difference in horizontal hydraulic conductivity was estimated between wells EEA-S4 and M4 (0.63 and $0.043 \mathrm{ft} / \mathrm{d}$, respectively) (table 1). Similarly, there is overlap in the ranges of vertical hydraulic conductivity for the two units (fig. 5). In these areas of direct contact, the Columbia aquifer and Nanjemoy-Marlboro confining unit can effectively combine to form a thick (greater than $50 \mathrm{ft}$ ) aquifer, and the Columbia aquifer can either contribute to, or receive ground water from, the Nanjemoy-Marlboro confining unit, depending on the direction and magnitude of the vertical hydraulic gradient. Such a hydraulic connection is indicated at cluster 4 by the fact that water levels in the two units are similar and respond to precipitation events in a parallel manner (fig. 13).

Well clusters 4,5 , and 7 are located in areas where the Columbia aquifer directly overlies the Nanjemoy-Marlboro confining unit. Cluster 4 (fig. 13) showed a slight downward gradient between the two screened zones of about 0.01 during the low-water period (for this study period, approximately June 1994 to January 1995), and little vertical gradient during the rest of the year. The water level data suggest that in areas of high land-surface elevation (greater than $20 \mathrm{ft}$ ) in the western area of the EEA, the Columbia aquifer can recharge the Nanjemoy-Marlboro confining unit. In contrast, well cluster 5 (fig. 13) showed a slight upward gradient of 0.005 to 0.01 over most of the study period, indicating that beneath the Churchill Test Area the Nanjemoy-Marlboro confining unit can discharge ground water to the Columbia aquifer. However, well cluster 7 (fig. 13) showed little to no vertical gradient for most of the study period except for a downward gradient of 0.005 to 0.05 in the spring and early summer of 1994.

\section{Upper Confined Aquifer}

Water levels in the upper confined aquifer generally are lower than those in the Columbia aquifer and the Nanjemoy-Marlboro confining unit, ranging from about $17 \mathrm{ft}$ above sea level during the high-water period in well EEA-M1 to just above sea level in well EEA-M3 (figs. 16 and 17). Well EEA-S2 is completed in the Nanjemoy-Marlboro confining unit just below the upper confined aquifer, but the water level at this well is probably close to the water level in the upper 


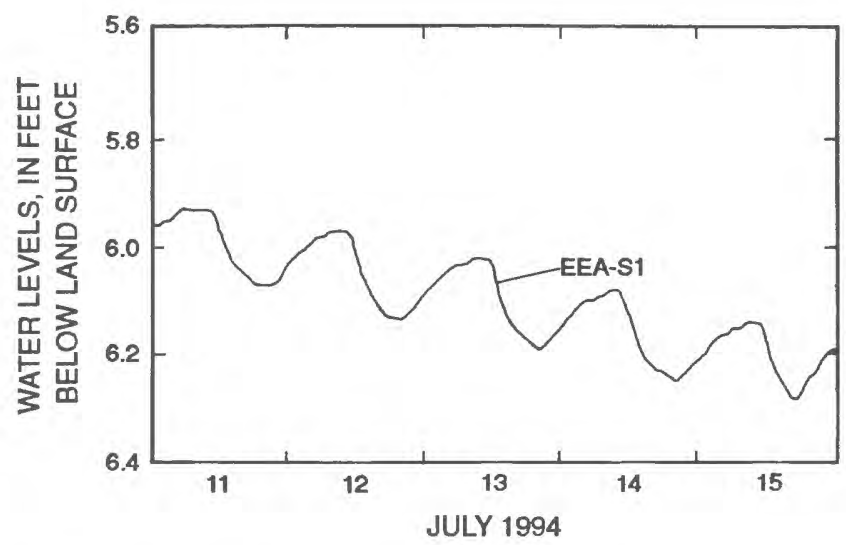

Figure 15. Water level in the Columbia aquifer for well EEAS1, July 11-15, 1995, at the Explosive Experimental Area, Dahlgren, Virginia.

confined aquifer. Water levels in the three upper confined aquifer wells near the shore of Machodoc Creek and the Potomac River (EEA-M3, M6, and M8) remained within a few feet of sea level throughout the year.

\section{Recharge}

Sediments of the upper confined aquifer occupy paleochannels cut into the Nanjemoy-Marlboro confining unit, and the upper confining unit overlies this aquifer at all well cluster locations, including those on the Mainside of the NSWCDL. Water-level data indicate that downward gradients exist between the Columbia aquifer and the upper confined aquifer at well clusters 1,6 , and 8 throughout the year, and at well cluster 2 during high-water conditions. Although the magnitude of these gradients ranges from $<0.001$ to as high as 0.20 , the low vertical permeability of the upper confining unit (median $2.0 \times 10^{-4} \mathrm{ft} / \mathrm{d}$ ) inhibits recharge across this unit. The upper confined aquifer, therefore, is probably recharged by a combination of flow across the upper confining unit and flow from the adjacent and underlying Nanjemoy-Marlboro confining unit.

A horizontal hydraulic gradient of 0.001 to 0.01 is estimated between the Nanjemoy-Marlboro confining unit beneath the central and western EEA and the upper confined aquifer beneath the southern part of the EEA. In high-permeability zones of the NanjemoyMarlboro confining unit (horizontal hydraulic conductivity of $0.5 \mathrm{ft} / \mathrm{d}$, assumed porosity of 0.30 ), these gradients could result in horizontal ground-water-flow rates of 0.6 to $6 \mathrm{ft}$ /year from the Nanjemoy-Marlboro confining unit to the upper confined aquifer, which are sufficient to maintain the observed hydraulic gradient in the upper confined aquifer. Horizontal hydraulic gradients between the two units are probably even higher south of the EEA because of the higher landsurface elevations on top of the Dahlgren scarp. The southern arm of the upper confined aquifer may act as a large subsurface drain to intercept flow from the uplands and divert it toward the Potomac River.

\section{Horizontal Flow and Discharge}

Water in the southem arm of the upper confined aquifer generally flows eastward-northeastward toward the Potomac River, as indicated by decreasing hydraulic head from well EEA-M1 to M2 to M3

(fig. 17); some ground water also may flow west from the vicinity of well EEA-M1 toward Machodoc Creek. The horizontal hydraulic gradient is about 0.002 to the east, which would result in ground-water-flow rates of about $0.03 \mathrm{ft} / \mathrm{d}$ assuming an average horizontal hydraulic conductivity of $4.0 \mathrm{ft} / \mathrm{d}$ and a porosity of 0.30 . The low hydraulic gradient results in relatively low ground-water-flow rates despite the permeable nature of the upper confined aquifer, and ground-water discharges directly to the Potomac River and

Machodoc Creek at an undetermined distance offshore where the river has breached the upper confining unit. Bathymetric contours indicate that the upper confining unit has been eroded away in some parts of the Potomac River channel, and possibly parts of the Machodoc Creek channel (U.S. Geological Survey and National Ocean Service, 1983).

Because only two wells are completed in the upper confined aquifer in the northern area of the EEA, exact ground-water-flow directions in this area are difficult to determine; however, ground water probably flows northward and eastward toward Machodoc Creek and the Potomac River. In the upper confined aquifer, the horizontal hydraulic gradient in the northern part of the EEA is much lower than that in the southern area because of lower rates of recharge through the Nanjemoy-Marlboro confining unit. Ground water discharges directly to the Potomac River and probably to Machodoc Creek where these surface-water bodies have breached the upper confining unit.

Wells EEA-M3, M6, and M8, all close to the shoreline of the EEA, show a marked tidal affect on the upper confined aquifer (fig. 18). These groundwater-level oscillations are caused by the transmission 


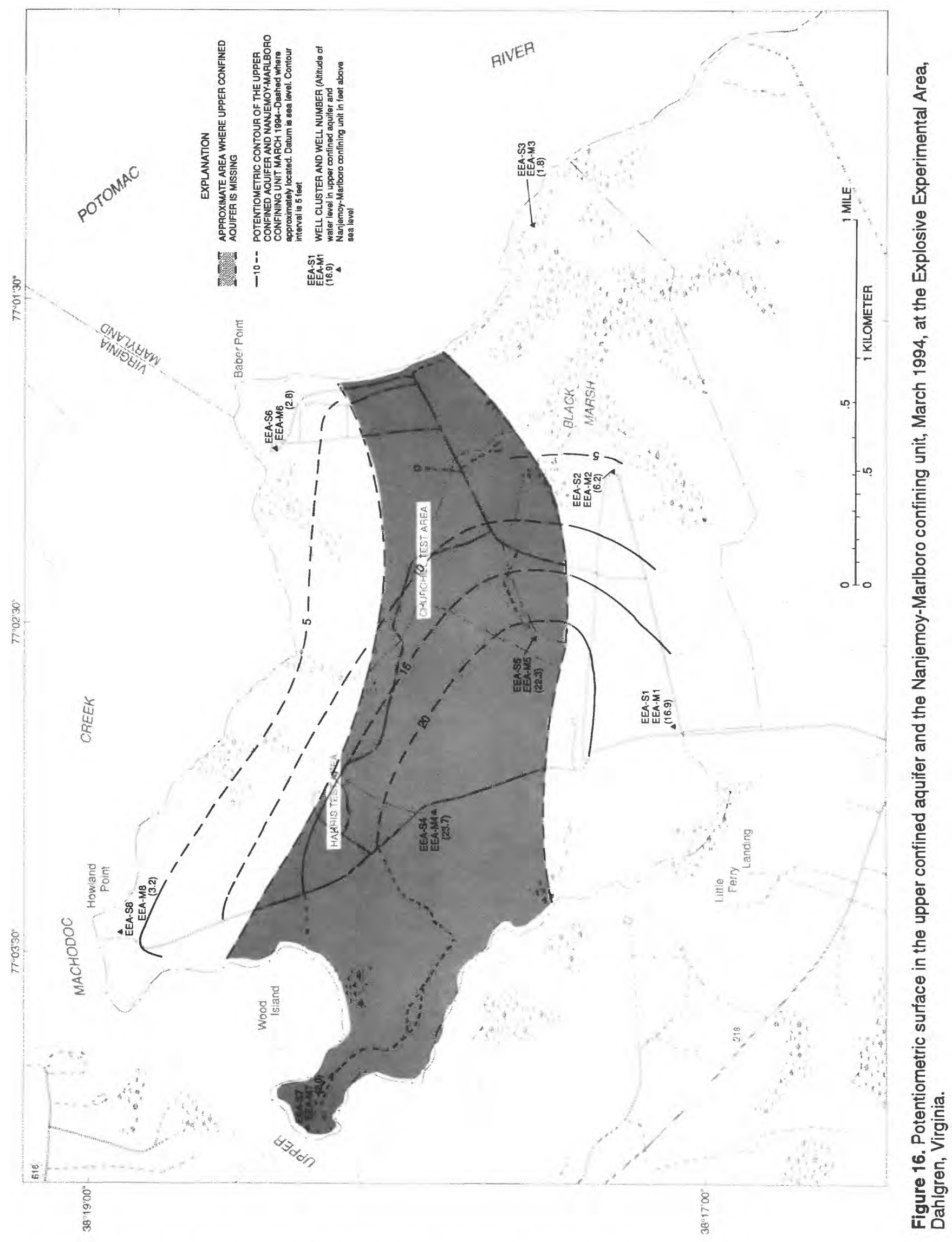




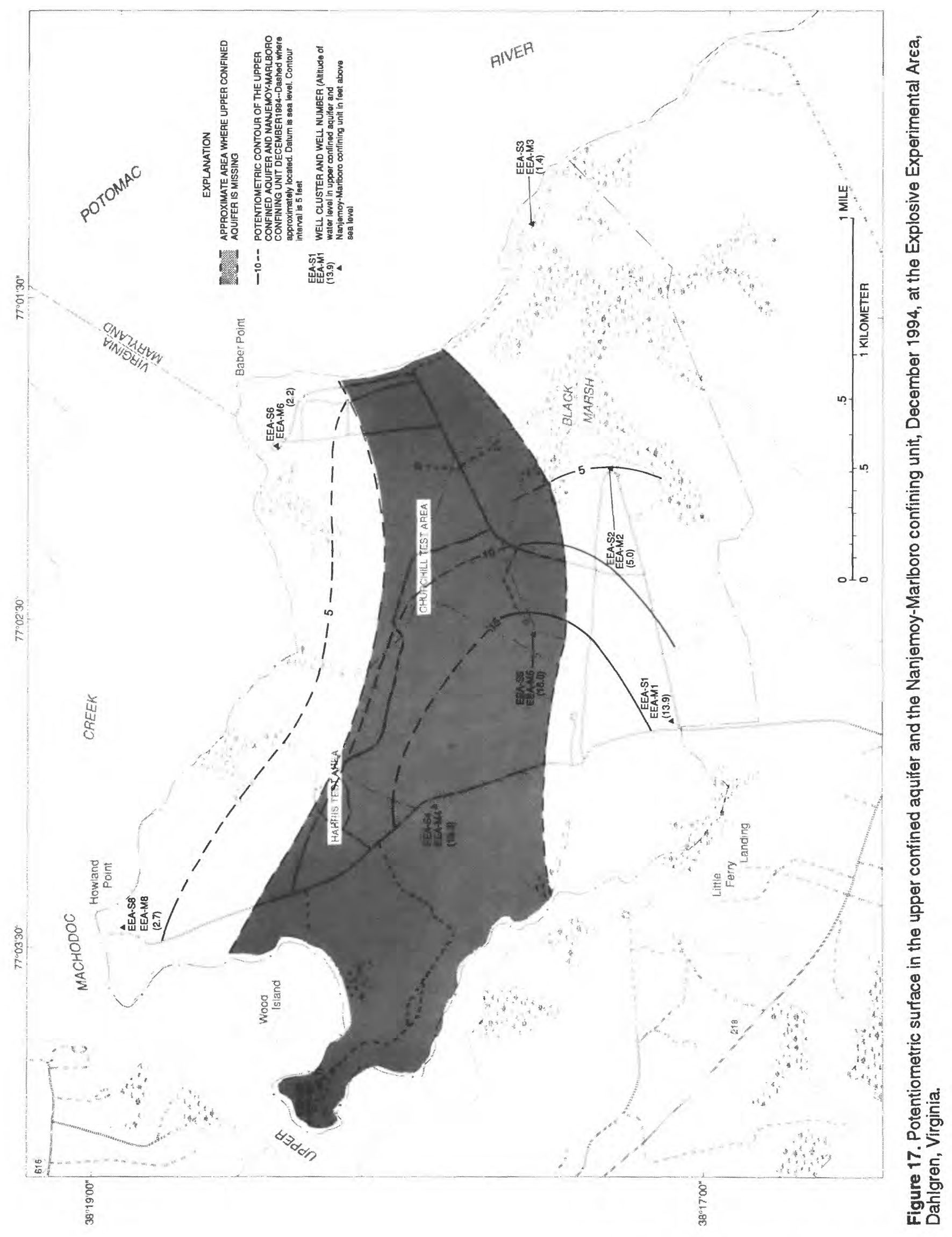




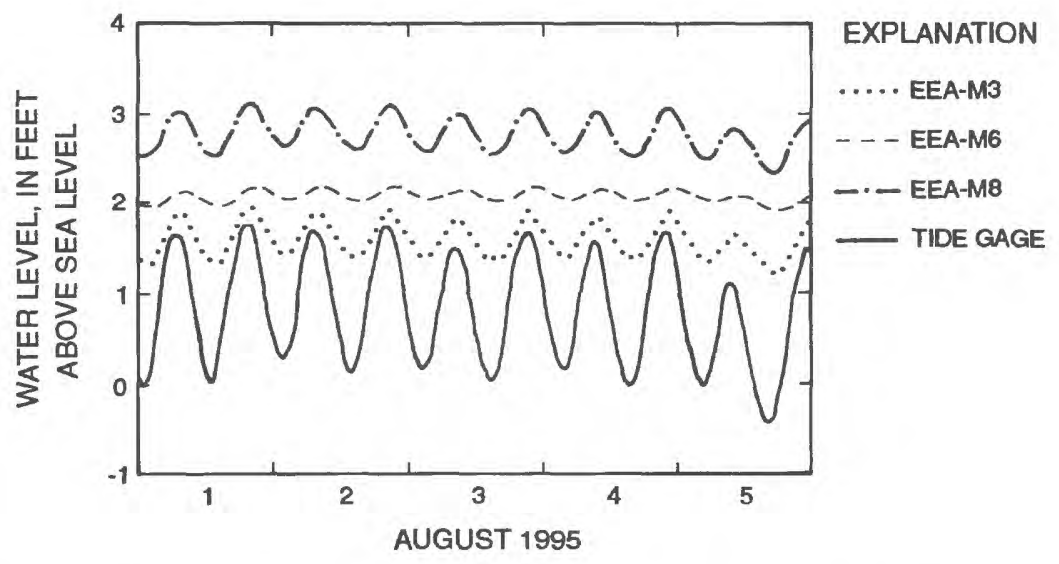

Figure 18. Water levels for wells EEA-M3, M6, M8, and tidal fluctuations in the Upper Machodoc Creek, August 1-5, 1995, at the Explosive

Experimental Area, Dahlgren, Virginia.

of large tidally induced pressure-head changes across the upper confining unit. It should be noted, however, that flow rates across the upper confining unit are still controlled by the low permeability of this unit, and there is little tidally induced flow between surface water and the upper confined aquifer at the EEA except where the upper confining unit is very thin or has been removed by erosion.

\section{WATER QUALITY OF THE SHALLOW AQUIFER SYSTEM}

The background quality of water in the shallow aquifer system at the EEA is typical of shallow ground water in the Virginia Atlantic Coastal Plain Physiographic Province (Virginia State Water Control Board, 1973; Richardson and Brockman, 1992), and is similar to the quality of water in the shallow aquifer system at the Mainside (Harlow and Bell, 1996). The following section describes the interpretation of water-quality data collected at the EEA, including quality assurance/ quality control (QA/QC) results and distribution of selected constituents.

\section{Quality Assurance and Quality Control}

Water-quality data were verified by examination of laboratory quality-assurance (QA) criteria, qualitycontrol (QC) samples, and cation-anion balances. Laboratory QA procedures are described in Friedman and
Erdmann (1982) and Jones (1987). QC samples collected in the field include duplicate samples, equipment blanks, and deionized water blanks. At least 1 QC sample was collected in duplicate for every 10 water-quality samples collected. QA goals were that the relative percent difference (RPD) of constituent concentrations in duplicate samples were not to exceed 20 percent. Chemical constituents were not to be present in the equipment and deionized water blanks at concentrations above the reporting limits. Cation-anion imbalances were not to be greater than 10 percent.

The only duplicate analyses of ground water that did not fall within 20 RPD were those for dissolved iron (well EEA-S6) and dissolved aluminum (well EEA-M6). Duplicate samples of surface water at site EEA-SW2 exceeded 20 RPD for field alkalinity and all three trace metals. These differences in measured concentrations were not large enough to affect interpretation of water-quality data.

Small concentrations of dissolved organic carbon $(0.3 \mathrm{mg} / \mathrm{L})$ were measured in the deionized water blank. Maximum concentrations of constituents detected in five equipment blank samples collected throughout the sampling period were $0.6 \mathrm{mg} / \mathrm{L}$ dissolved organic carbon, $0.2 \mathrm{mg} / \mathrm{L}$ suspended organic carbon, $0.03 \mathrm{mg} / \mathrm{L}$ dissolved calcium, $2.3 \mathrm{mg} / \mathrm{L}$ dissolved chloride, $0.50 \mathrm{mg} / \mathrm{L}$ dissolved silica, $48 \mu \mathrm{g} / \mathrm{L}$ dissolved iron, $2.1 \mathrm{mg} / \mathrm{L}$ alkalinity as $\mathrm{CaCO}_{3}, 2 \mu \mathrm{g} / \mathrm{L}$ dissolved manganese, and $20 \mu \mathrm{g} / \mathrm{L}$ dissolved aluminum. Although these concentrations were not high enough to affect interpretation of water-quality data, it 
should be recognized that water-quality constituents at, or below, these concentrations could have been derived from the sampling pump or tubing.

Of 28 wells sampled for water-quality, only 2 had cation-anion balances that exceeded 10 percent: wells EEA-S11 and S15 had balances of 17.3 percent and -10.6 percent, respectively. Cation-anion imbalances indicate an error in the measurement of some ion(s), or that an unmeasured ion (for example, nitrate) was present in a significant concentration. Waterquality analyses from these two wells should be interpreted with caution, but the difference does not affect the overall interpretation of water-quality data. Cationanion balances did not exceed 10 percent in any of the three surface-water samples.

\section{Occurrence and Distribution of Selected Chemical Constituents}

The range in values of selected chemical constituents in the Columbia aquifer, upper confined aquifer, and the Nanjemoy-Marlboro confining unit is discussed with regard to spatial distribution on the NSWCDL and U.S. Environmental Protection Agency (1995) secondary maximum contaminant levels (SMCL's) or Virginia Department of Environmental Quality Ground-Water Standards (VGWS's) for drinking water, which are nonenforceable standards established on the basis of aesthetic concerns, such as taste and odor. Reporting limits and water-quality data for wells and surface-water sampling sites at the EEA are published in Hammond and Bell (1995).

\section{Columbia Aquifer}

Maximum, minimum, and median values of constituent concentrations and field parameters in the Columbia aquifer are presented in table 2 , and boxplot summaries of water-quality data from three hydrogeologic units are shown in figure 19. A trilinear plot (fig. 20) shows the relative major-ion distribution of water from all 20 wells completed in the Columbia aquifer.

\section{Field Parameters and Indicators}

Water in the Columbia aquifer is characterized by low $\mathrm{pH}$; samples from 18 of 20 wells had $\mathrm{pH}$ below the SMCL range of 6.5 to 8.5. Low pH in shallow ground water commonly is a result of precipitation reacting with carbon dioxide in the atmosphere and soil zone, which produces carbonic acid (Hem, 1989). Deeper, older water usually has reacted with buffering minerals in aquifers, such as calcite, which raise $\mathrm{pH}$ (and alkalinity). Dissolved oxygen concentration varied from less than 1 to $9.0 \mathrm{mg} / \mathrm{L}$ across the EEA, and represent local differences in atmospheric connection, recharge rate, and organic content of Columbia aquifer sediments.

Other field parameters and indicators, such as specific conductance, total dissolved solids (TDS), and alkalinity, are highly variable in the Columbia aquifer. At well EEA-S3, which has a direct connection with the Potomac River, much higher specific conductance, TDS, and alkalinity values are present than at any other well $(7,600 \mu \mathrm{S} / \mathrm{cm}, 4,510 \mathrm{mg} / \mathrm{L}$, and $489 \mathrm{mg} / \mathrm{L}$ as $\mathrm{CaCO}_{3}$, respectively). The highest concentrations of all major ions also were measured at well EEA-S3. Water in most wells completed in the Columbia aquifer had specific conductance below $300 \mu \mathrm{S} / \mathrm{cm}$, TDS less than $200 \mathrm{mg} / \mathrm{L}$, and alkalinity below $100 \mathrm{mg} / \mathrm{L}$ as $\mathrm{CaCO}_{3}$ (fig.19).

Three of the six alkalinity values greater than $100 \mathrm{mg} / \mathrm{L}$ as $\mathrm{CaCO}_{3}$ were measured at wells EEA-S4, S9, and S10, which correspond to an area where the Nanjemoy-Marlboro confining unit lies within $10 \mathrm{ft}$ of land surface. Dissolution of fossil shell material in this unit caused the high alkalinities. Relatively high alkalinities at wells EEA-S6 and S19 could be due to dissolution of shell material in artificial fill sediments.

\section{Major Constituents}

Water from the Columbia aquifer has variable major-ion composition (fig. 20). Dominant cations measured were calcium and sodium, with lesser percentages of magnesium, whereas dominant anions were bicarbonate and sulfate, with low to moderate percentages of chloride.

The most common single water type in the Columbia aquifer was calcium-bicarbonate, measured at four wells (EEA-S4, S9, S18, and S19) where the Columbia aquifer overlies the Nanjemoy-Marlboro confining unit. Most Columbia aquifer wells yielded water of a mixed-ionic character, however, and the median concentrations of all major ions were less than $20 \mathrm{mg} / \mathrm{L}$. Low-ionic strength water of mixed-ionic composition is common in shallow ground water in the Coastal Plain Physiographic Province of Virginia (Richardson and Brockman, 1992; Harlow and Bell, 1996). Major ions, such as calcium, sodium, bicarbonate, sulfate, and chloride, are derived mainly from 

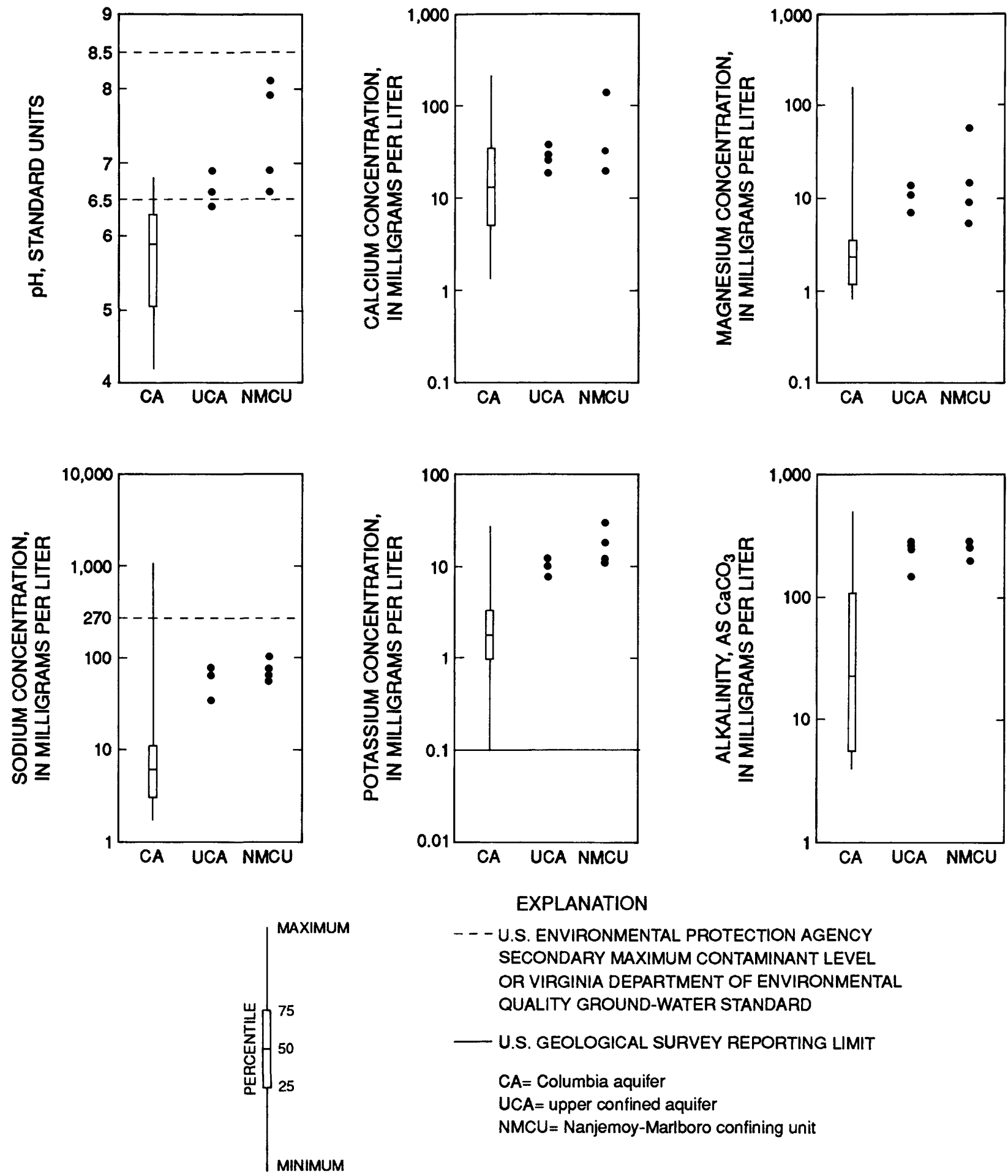

EXPLANATION

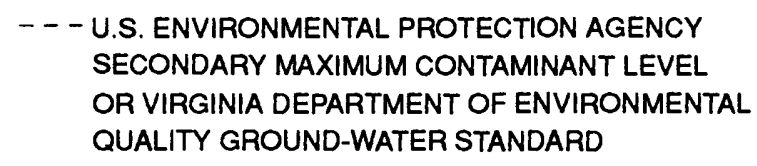

U.S. GEOLOGICAL SURVEY REPORTING LIMIT

$\mathrm{CA}=$ Columbia aquifer $\mathrm{UCA}=$ upper confined aquifer $\mathrm{NMCU}=$ Nanjemoy-Marlboro confining unit

MINIMUM

Figure 19. Summaries of water-quality analyses for selected constituents in ground water at the Explosive Experimental Area, Dahlgren, Virginia. (Results from 20 analyses were used for all boxplots except that of aluminum, which used 19.) 

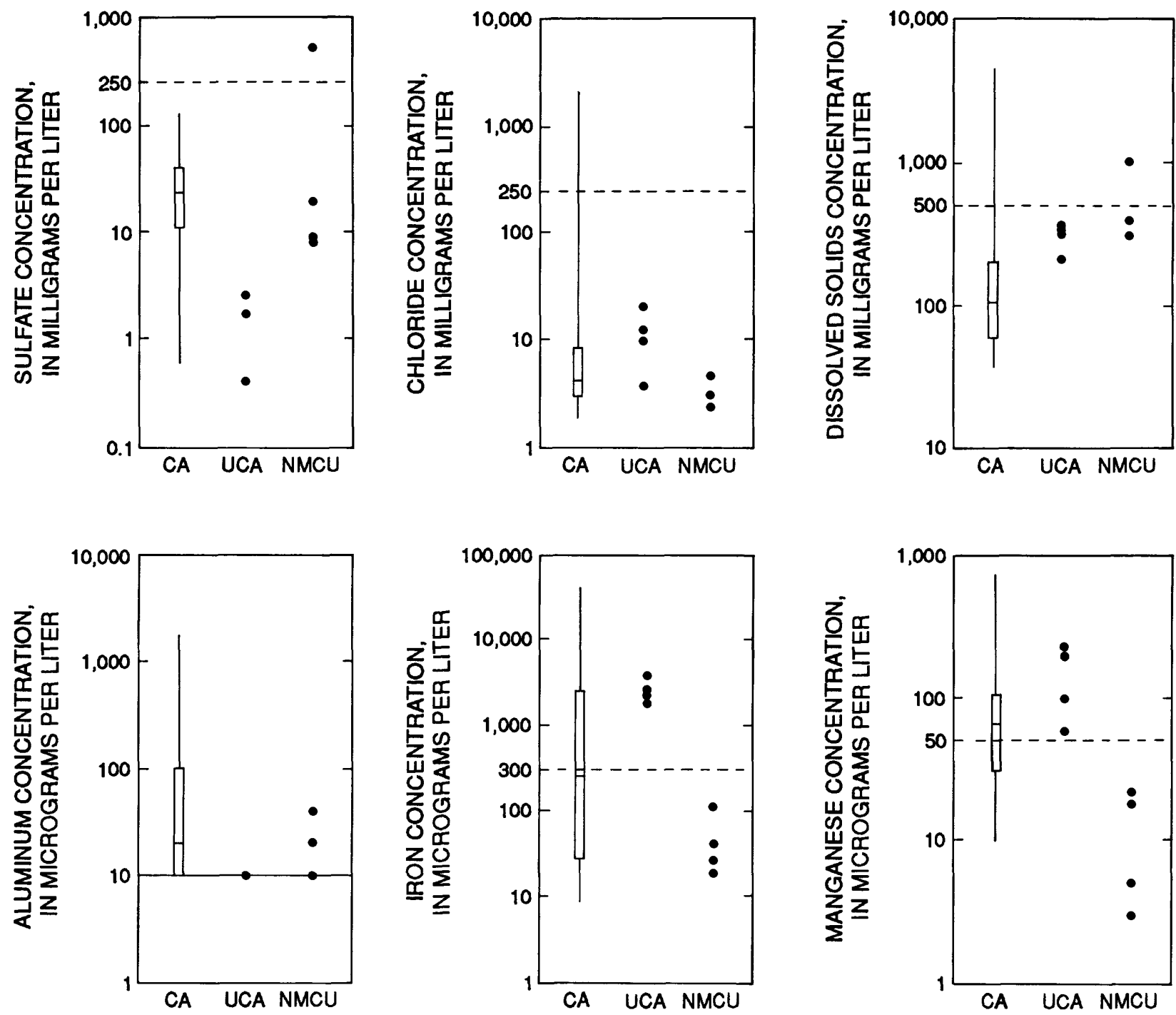

Figure 19.-Continued.

precipitation, mineral dissolution, and degradation of organic material in the subsurface (Hem, 1989; Drever, 1988).

EEA-S3 was the only well with a sodiumchloride water type, and the only well to exceed the VGWS for sodium and the SMCL for chloride. The major-ion composition, specific conductance, and concentration of total dissolved solids of water from well EEA-S3 is very similar to that from the surface-water site, SW-1 (fig. 21), providing more evidence of a direct connection of the Columbia aquifer and surface water at this location. No other wells (even those that are close to the shoreline such as EEA-S6, S7, and S8) contained water that was similar in chemical composition to surface-water samples. It appears, therefore, that surface water has little direct effect on groundwater quality at the EEA except possibly in a narrow zone adjacent to the shoreline. The Potomac River, however, may affect ground-water quality indirectly by generating aerosols (sea spray) and, thereby, increasing the sodium and chloride concentrations of local precipitation.

\section{Minor Constituents}

Dissolved iron and manganese displayed a wide range in concentration in the Columbia aquifer (fig. 19); iron ranged from 10 to $40,000 \mu \mathrm{g} / \mathrm{L}$, whereas manganese ranged from 9 to $550 \mu \mathrm{g} / \mathrm{L}$. Iron and manganese concentrations are controlled by local redox 
conditions. In oxidizing conditions, both iron and manganese exist in relatively insoluble forms. Where oxygen has been depleted by microbial degradation of organic matter, however, iron and manganese in aquifer minerals can be reduced to much more soluble forms. High concentrations of these constituents indicate local reducing conditions in the Columbia aquifer. Dissolved aluminum also showed a wide range in concentration, ranging from less than 10 to $1,700 \mu \mathrm{g} / \mathrm{L}$. Aluminum is derived from dissolution of several silicate minerals, including clays, and aluminum concentrations are controlled largely by local differences in pH (Hem, 1989).

Both dissolved organic carbon (DOC) and suspended organic carbon (SOC) were present in water at all wells completed in the Columbia aquifer, mostly at relatively low (less than $5 \mathrm{mg} / \mathrm{L}$ ) concentrations. Naturally occurring DOC and SOC are derived from organic material both in the soil zone and aquifer sediments, so detection of these constituents does not necessarily indicate ground-water contamination.

Anthropogenic contamination might be indicated by concentrations of DOC and (or) SOC that are significantly higher than background levels.

\section{Nanjemoy-Marlboro Confining Unit}

Water from the Nanjemoy-Marlboro confining unit generally exhibited higher $\mathrm{pH}$, specific conductance, TDS, and alkalinity than water from the Columbia aquifer (fig. 19). Water samples from all four wells

Table 2. Summary statistics for water-quality analyses from the Columbia aquifer at the Explosive Experimental Area, Dahlgren, Virginia

[all analyses are for the dissolved constituent; results from 20 analyses were used to calculate all statistics unless otherwise noted; --, no SMCL exists for this constituent; ${ }^{\circ} \mathrm{C}$, degrees Celsius; $\mu \mathrm{g} / \mathrm{L}$, micrograms per liter, $\mathrm{mg} / \mathrm{L}$, milligrams per liter; $\mu \mathrm{S} / \mathrm{cm}$, microsiemens per centimeter at $25^{\circ} \mathrm{C}$; $<$, less than; C, carbon; $\mathrm{CaCO}_{3}$, calcium carbonate; SMCL, U.S. Environmental Protection Agency, (1995) secondary maximum contaminant level; VGWS, Virginia Department of Environmental Quality ground-water standard]

\begin{tabular}{|c|c|c|c|c|c|}
\hline Water-quality constituent & $\begin{array}{c}\text { Maximum } \\
\text { concentration }\end{array}$ & $\begin{array}{c}\text { Minimum } \\
\text { concentration }\end{array}$ & $\begin{array}{c}\text { Median } \\
\text { concentration }\end{array}$ & $\begin{array}{l}\text { SMCL } \\
\text { or } \\
\text { vGWS }\end{array}$ & $\begin{array}{l}\text { Number of } \\
\text { samples } \\
\text { exceeding } \\
\text { SMCL } \\
\text { VGWS }\end{array}$ \\
\hline Specific conductance, $\mu \mathrm{S} / \mathrm{cm}$ & 7,600 & 48 & 151 & -- & -- \\
\hline $\mathrm{pH}$, standard units & 6.8 & 4.2 & 5.9 & $6.5-8.5$ & 18 \\
\hline${ }^{1}$ Dissolved oxygen, mg/L & 9.0 & .2 & 4.3 & -- & -- \\
\hline Calcium, $\mathrm{mg} / \mathrm{L}$ & 220 & 1.4 & 13 & -- & -- \\
\hline Magnesium, mg/L & 160 & .82 & 2.2 & -- & -- \\
\hline Sodium, mg/L & 1,100 & 1.8 & 6.2 & 270 & 1 \\
\hline Potassium, mg/L & 27 & $<.10$ & 1.6 & -- & -. \\
\hline Alkalinity, $\mathrm{mg} / \mathrm{L}$ as $\mathrm{CaCO} 3$ & 489 & 4 & 22 & -- & -- \\
\hline Sulfate, $\mathrm{mg} / \mathrm{L}$ & 130 & .60 & 16 & 250 & 0 \\
\hline Chloride, $\mathrm{mg} / \mathrm{L}$ & 2,100 & 1.9 & 4.1 & 250 & 1 \\
\hline Fluoride, $\mathrm{mg} / \mathrm{L}$ & 1.5 & $<.10$ & .10 & -- & -- \\
\hline Silica, mg/L & 46 & 9.9 & 20 & -- & -- \\
\hline Dissolved solids, residue at $180^{\circ} \mathrm{C}, \mathrm{mg} / \mathrm{L}$ & 4,510 & 37 & 106 & 500 & 1 \\
\hline${ }^{2}$ Aluminum, $\mu \mathrm{g} / \mathrm{L}$ & 1,700 & $<10$ & 20 & -- & -- \\
\hline Iron, $\mu \mathrm{g} / \mathrm{L}$ & 40,000 & 9 & 230 & 300 & 9 \\
\hline Manganese, $\mu \mathrm{g} / \mathrm{L}$ & 550 & 10 & 59 & 50 & 11 \\
\hline${ }^{3}$ Dissolved organic carbon, $\mathrm{mg} / \mathrm{L}$ as $\mathrm{C}$ & 14 & .6 & 1.4 & 1 & 16 \\
\hline
\end{tabular}

\footnotetext{
${ }^{1}$ Results from 18 analyses were used to calculate statistics for dissolved oxygen.

${ }^{2}$ Results from 19 analyses were used to calculate statistics for aluminum.

${ }^{3}$ Results from 17 analyses were used to calculate statistics for dissolved organic carbon.
} 


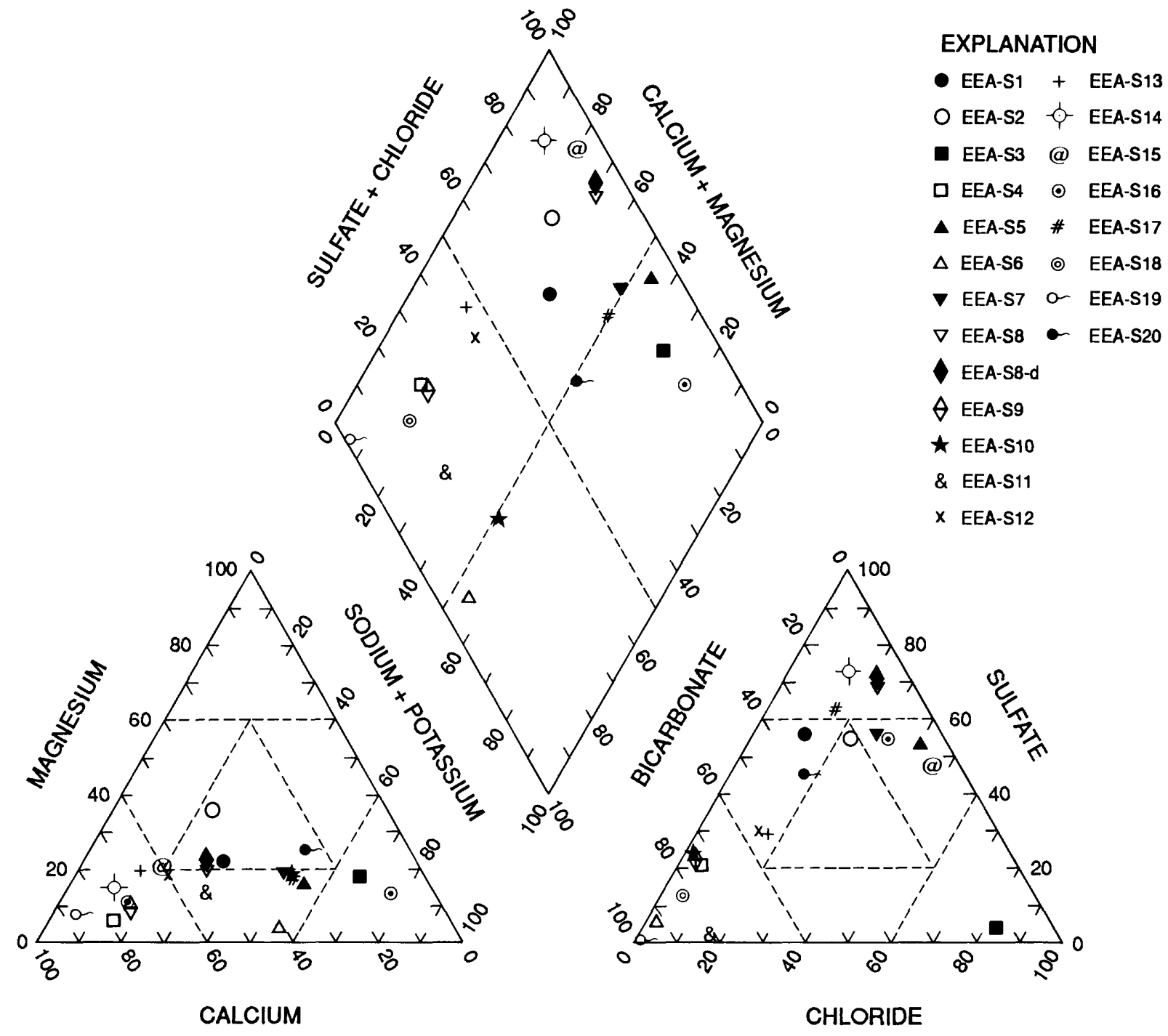

PERCENT OF TOTAL MILLIEQUIVALENTS PER LITER

Figure 20. Major-ion composition of water from wells completed in the Columbia aquifer at the Explosive Experimental Area, Dahlgren, Virginia.

completed in this unit were within the SMCL pH range of 6.5 to 8.5 . Specific conductance ranged from $535 \mu \mathrm{S} / \mathrm{cm}$ at well EEA-M2 to $1,330 \mu \mathrm{S} / \mathrm{cm}$ at well EEA-M7, and TDS ranged from $304 \mathrm{mg} / \mathrm{L}$ at well EEA-M2 to $1,010 \mathrm{mg} / \mathrm{L}$ at well EEA-M7. Alkalinity was less variable, and ranged from $198 \mathrm{mg} / \mathrm{L}$ as $\mathrm{CaCO}_{3}$ at well EEA-M7 to $285 \mathrm{mg} / \mathrm{L}$ as $\mathrm{CaCO}_{3}$ at well EEA-M4. Water in two of the four wells completed in the Nanjemoy-Marlboro confining unit (EEA-M4 and M5) contained significant concentrations of dissolved oxygen $(2.3$ and $6.0 \mathrm{mg} / \mathrm{L}$, respectively), possibly due to the downward flow of oxygen- containing water from the overlying Columbia aquifer. Concentrations of trace metals such as iron, manganese, and aluminum were generally similar to, or lower than, the Columbia aquifer medians. Concentrations of DOC were slightly higher than the Columbia aquifer median, ranging from $3.8 \mathrm{mg} / \mathrm{L}$ at well EEAM7 to $7.7 \mathrm{mg} / \mathrm{L}$ at well EEA-M2.

A trilinear plot of water-quality data from the Nanjemoy-Marlboro confining unit (fig. 21) shows that sodium, or a combination of sodium and calcium, are the dominant cations at all four wells completed in this unit; however, no samples exceeded the VGWS 


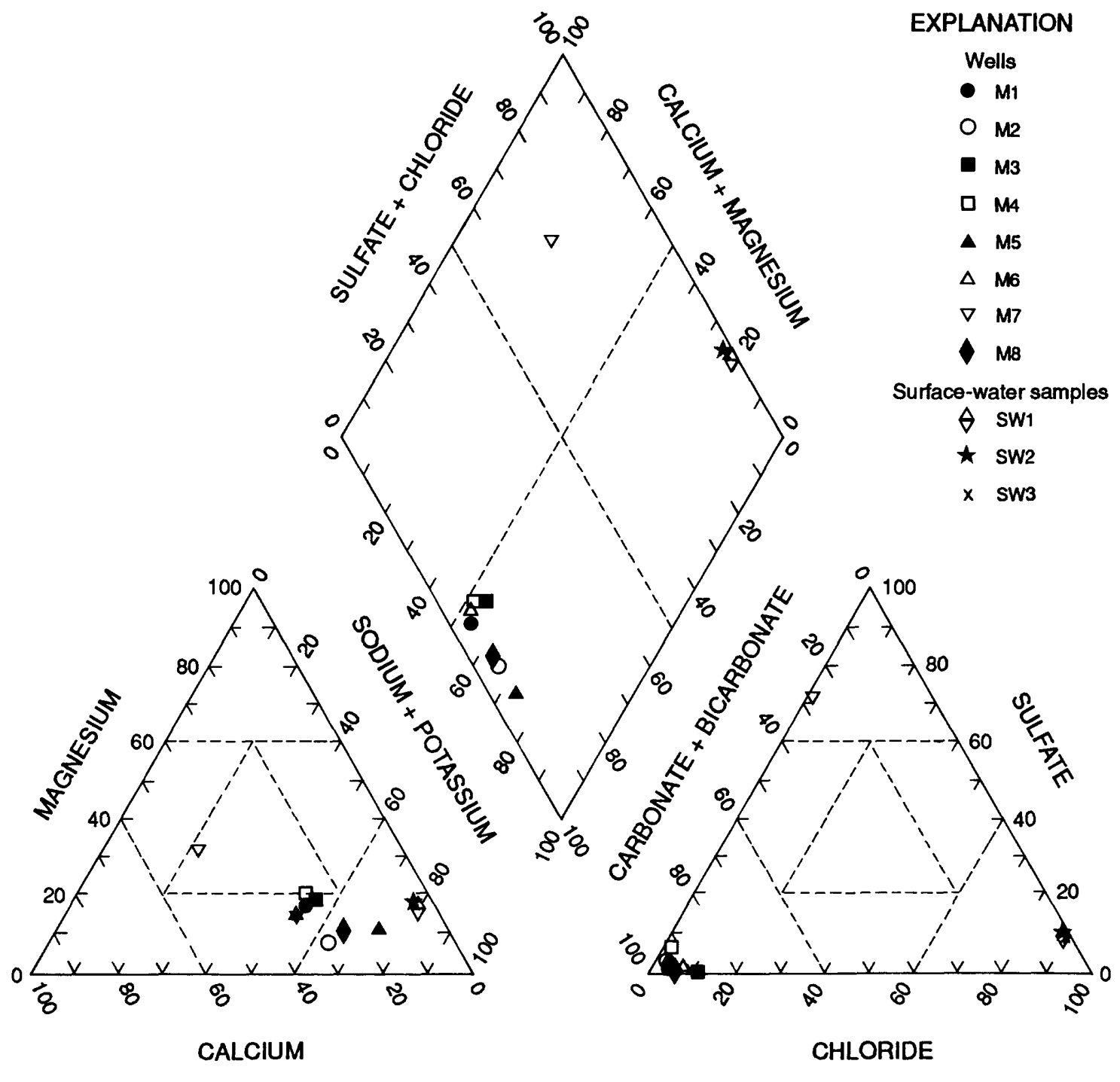

PERCENT OF TOTAL MILLIEQUIVALENTS PER LITER

Figure 21. Major-ion composition of water from wells completed in the upper confined aquifer and Nanjemoy-Marlboro confining unit at the Explosive Experimental Area, Dahlgren, Virginia.

for sodium of $270 \mathrm{mg} / \mathrm{L}$. Bicarbonate was the major anion at three of the wells (EEA-M2, M4, and M5), whereas sulfate was the dominant anion at well EEA-M7. The sulfate concentration of $510 \mathrm{mg} / \mathrm{L}$ at well EEA-M7 exceeded the SMCL of $250 \mathrm{mg} / \mathrm{L}$.

The water quality of the Nanjemoy-Marlboro confining unit is controlled by dissolution of carbonate minerals and cation exchange. As low-pH, lowalkalinity water from the Columbia aquifer moves downward into the underlying Nanjemoy-Marlboro confining unit, it dissolves fossil shell material composed of calcium carbonate $\left(\mathrm{CaCO}_{3}\right)$, which raises the $\mathrm{pH}$, specific conductance, TDS, and alkalinity. The resulting calcium-bicarbonate water is further modified by exchange of sodium for calcium on surfaceactive minerals such as glauconite (Chapelle and Knobel, 1983), resulting in a sodium-calciumbicarbonate water type. High concentration of sulfate at well EEA-M7 may have been derived from microbial oxidation of organic matter or sulfur-containing minerals such as pyrite $\left(\mathrm{FeS}_{2}\right)$.

\section{Upper Confined Aquifer}

The water quality of the upper confined aquifer is similar to that of the Nanjemoy-Marlboro confining unit for many constituents (fig. 19). Values of $\mathrm{pH}$ were 
slightly lower than those of the confining unit, with measurements from one (EEA-M1) out of the four wells falling below the lower SMCL of 6.5. Specific conductance ranged from $338 \mu \mathrm{S} / \mathrm{cm}$ at well EEA-M1 to $600 \mu \mathrm{S} / \mathrm{cm}$ at well EEA-M3, and TDS ranged from $210 \mathrm{mg} / \mathrm{L}$ at well EEA-M1 to $368 \mathrm{mg} / \mathrm{L}$ at well EEAM6. Alkalinity in the upper confined aquifer was very similar to that of the Nanjemoy-Marlboro confining unit, ranging from $146 \mathrm{mg} / \mathrm{L}$ at well EEA-M1 to $279 \mathrm{mg} / \mathrm{L}$ at well EEA-M8. Unlike the wells completed in the confining unit, however, none of the four wells completed in the upper confined aquifer contained concentrations of dissolved oxygen greater than $1 \mathrm{mg} / \mathrm{L}$.

The major-ion composition of water in the upper confined aquifer is similar to that of the Nanjemoy-Marlboro confining unit. Concentrations of calcium, magnesium, sodium, potassium, and chloride are in the same range as that of the NanjemoyMarlboro confining unit and are significantly higher than Columbia aquifer medians (fig. 19). A trilinear plot indicates that water from wells in the upper confined aquifer has a sodium-calcium-bicarbonate water type, with the exception of water at well EEA-M8, which has a sodium-bicarbonate water type (fig. 21).

Two important differences stand out between the water quality of the upper confined aquifer and that of the Nanjemoy-Marlboro confining unit. The aquifer has much lower concentrations of sulfate and much higher concentrations of the redox-sensitive trace metals, iron and manganese. In fact, all four wells in the upper confined aquifer exceeded the SMCL's for iron and manganese of 300 and $50 \mathrm{mg} / \mathrm{L}$, respectively.

The water quality of the upper confined aquifer is consistent with the previously described conceptual flow system in which water recharges the upper confined aquifer through the Nanjemoy-Marlboro confining unit. High-alkalinity sodium-calcium-bicarbonate water from the Nanjemoy-Marlboro confining unit moves laterally into the upper confined aquifer, which itself contains little shell material. Microbial oxidation of the abundant organic matter in the upper confined aquifer, however, consumes any dissolved oxygen present in water from the confining unit, reduces sulfate to sulfide, and reduces iron and manganese to more soluble forms.

\section{SUMMARY}

The shallow aquifer system at the EEA consists of two fining-upward sequences of Pleistocene fluvialestuarine deposits that overlie marine deposits of the Nanjemoy-Marlboro confining unit of Eocene age. The surficial hydrogeologic unit is the Columbia aquifer that generally is unconfined and consists of deposits of the Sedgefield Member of the Tabb Formation. These fluvial-estuarine deposits range from clay to coarse-grained sand and pebbles and have varied hydraulic properties. Horizontal linear flow of water in the Columbia aquifer is affected strongly by lithologic heterogeneities, such as paleochannels and thin beds of clay. The Columbia aquifer receives recharge from infiltration of precipitation, and water generally flows according to surface topography, discharging to tidal creeks, marshes and the Potomac River. Locally, ground water discharges to Machodoc Creek by way of surface springs. Horizontal linear flow rates of water in the Columbia aquifer range from 0.003 to $0.70 \mathrm{ft} / \mathrm{d}$ on average, but can vary greatly depending on the local gradient and hydraulic characteristics.

The Columbia aquifer unconformably overlies the upper confining unit - an organic-rich clay having low permeability. The upper confining unit conformably overlies the upper confined aquifer, which consists of interbedded fine-grained to medium-grained sands and clay with a pebble lag. The upper confining unit and upper confined aquifer represent a single Pleistocene channel-fill sequence, and a gradational contact between the two units. The erosional surface incised by the paleochannel into the underlying Eocene deposits has more than $80 \mathrm{ft}$ of relief across the EEA, and the upper confined system is not present in the paleointerfluvial areas. The upper confined aquifer probably receives most of its recharge from the adjacent and underlying Nanjemoy-Marlboro confining unit. Water in the upper confined aquifer generally flows about $0.03 \mathrm{ft} / \mathrm{d}$ toward the Potomac River and Machodoc Creek. Near the westem shoreline of the EEA, water in the upper confined aquifer may flow westward toward Machodoc Creek.

The upper confined aquifer unconformably overlies the Nanjemoy-Marlboro confining unit, which consists of glauconitic, fossiliferous silty fine-grained sands of the Nanjemoy Formation of Eocene age. The upper confined system is absent in an eastern-western trending band across the center of the EEA; in this area the Columbia aquifer directly overlies the Nanjemoy-Marlboro confining unit. In some areas of 
the EEA, vertical hydraulic conductivities of the Nanjemoy-Marlboro confining unit and Columbia aquifer are similar. In these areas, the Columbia aquifer and Nanjemoy-Marlboro confining unit can effectively combine to form a thick (greater than $50 \mathrm{ft}$ ) unconfined aquifer.

Water quality of the shallow aquifer system is typical of shallow ground water elsewhere in the Virginia Coastal Plain Physiographic Province. Water in the Columbia aquifer is a mixed-ionic type characterized by low $\mathrm{pH}$, alkalinity, and TDS. This composition is indicative of infiltrated precipitation that has reacted with carbon dioxide in the soil zone and aquifer sediments, but has not been significantly buffered by dissolution of carbonate or silicate minerals. Water in the upper confined aquifer and Nanjemoy-Marlboro confining unit is a sodium-calcium-bicarbonate water type characterized by moderate to high $\mathrm{pH}$, TDS, and alkalinity. This composition is indicative of ground water that has reacted with carbonate minerals and undergone ion-exchange processes. Anoxic conditions in the upper confined aquifer and parts of the Columbia aquifer have resulted in high concentrations of dissolved iron and manganese, and low concentrations of sulfate.

\section{REFERENCES CITED}

Bell, Clifton F., Bolles, Thomas P. and Harlow, George E. Jr., 1994, Hydrogeologic and Water-Quality Data for the Main Site, Naval Surface Warfare Center, Dahlgren Laboratory, Dahlgren, Virginia: U.S. Geological Survey Open-File Report 94-301, 81 p.

Bouwer, H., 1989, The Bouwer and Rice slug test-an update: Ground Water, v. 27, no. 3, p. 304-309.

Bouwer, H., and Rice, R. C., 1976, A slug test for determining hydraulic conductivity of unconfined aquifers with completely or partially penetrating wells: Water Resources Research, v. 12, no. 3, p. 423-428.

Chapelle, F.H., and Knobel, L.L., 1983, Aqueous geochemistry and the exchangeable cation composition of glauconite in the Aquia aquifer, Maryland: Ground Water, v. 21, p. 343-352.

Colman, S.M, Halka, J.P., Hobbs, C.H., III, Mixon, R.B., and Foster, D.S., 1990, Ancient channels of the Susquehanna River beneath Chesapeake Bay and the Delmarva Peninsula: Geological Society of America Bulletin, v. 102, p. 1,268-1,279.

Colman, S.M., and Mixon, R.B., 1988, The record of major quaternary sea-level changes in a large Coastal Plain estuary, Chesapeake Bay, eastern United States:
Paleogeography, Paleoclimatology, Paleoecology, v. 68, p. 99-116.

Cooper, H.H., Jr., Bredehoeft, J.D., and Papadopulos I.S., 1967, Response of a finite-diameter well to an instantaneous charge of water: Water Resources Research, v. 3, no. 1, p. 263-269.

Drever, J.I., 1988, The geochemistry of natural waters: Prentice-Hall, Inc., Englewood Clifis, NJ, 437 p.

Edwards, Thomas K., and Glysson, G. Douglas, 1988, Field methods for measurement of fluvial sediment: U.S. Geological Survey Open-File Report 86-531, 118 p.

Fishman, M.J., and Friedman, L.C., 1989, Methods for the determination of inorganic substances in water and fluvial sediments (3d ed.): U. S. Geological Survey Techniques of Water-Resources Investigations, book 5 , chap. Al, 545 p.

Fred C. Hart Associates, 1983, Initial Assessment Study of Naval Surface Weapons Center/Dahlgren Laboratory: Naval Energy and Environmental Support Activity, contract no. N62474-81-C-9384, 68 p.

Friedman, L.C., and Erdmann, D.E., 1982, Quality assurance practices for the chemical and biological analyses of water and fluvial sediments: U. S. Geological Survey Techniques of Water-Resources Investigations, book 5, chap. A6, $181 \mathrm{p}$.

Halliburton NUS, 1995, Final Installation Restoration Site Management Plan for the Naval Surface Warfare Center Dahlgren Laboratory, Dahlgren, Virginia: Northern Division Naval Facilities Engineering Command, contract no. N62472-9D-D-1298, contract task order $0118,76 \mathrm{p}$.

Hammond, E.C., and Bell, C.F., 1995, Hydrogeologic and water-quality data for the Explosive Experimental Area, Naval Surface Warfare Center, Dahlgren Site at Dahlgren, Virginia: U.S. Geological Survey Open-File Report 95-386, 68 p.

Harlow, G.E., Jr., and Bell, C.F., 1996, Hydrogeology and water-quality of the shallow aquifer system at the Mainside, Naval Surface Warfare Center, Dahlgren Site, Dahlgren, Virginia: U.S. Geological Survey Water-Resources Investigations Report 96-4055, 34 p.

Harsh, J.F., and Laczniak, R.J., 1990, Conceptualization and analysis of ground-water flow system in the Coastal Plain of Virginia and adjacent parts of Maryland and North Carolina: U.S. Geological Survey Professional Paper 1404-F, $100 \mathrm{p}$.

Hem, J.D., 1989, Study and interpretation of the chemical characteristics of natural water: U.S. Geological Survey Water-Supply Paper 2254, 263 p.

Jones, B.E., 1987, Quality control manual of the U. S. Geological Survey's National Water Quality Laboratory: U.S. Geological Survey Open-File Report 87-451, $17 \mathrm{p}$. 
Kerhin, R.T., Halka, J.P., and Conkwright, R.D., 1980, Identification of a paleochannel system under the eastern flank of Chesapeake Bay: Abstracts with programs, 1980 annual meeting of the Geological Society of America, p. 461.

Meng, A.A., III, and Harsh, J.F., 1988, Hydrogeologic framework of the Virginia Coastal Plain: U. S. Geological Survey Professional Paper 1404-C, 82 p.

Mixon, R.B., Berquist, C.R. Jr., Newell, W.L., and Johnson, G.H., 1989, Geologic map and generalized cross sections of the Coastal Plain and adjacent parts of the Piedmont, Virginia: U. S. Geological Survey Miscellaneous Investigations Series, Map I-2033, 2 sheets.

O'Brien and Gere Engineers, Inc., 1986, Confirmation studies at Naval Surface Weapons Center, Dahlgren, Virginia: Chesapeake Division Naval Facilities Engineering Command, contract no. P11 N62477-83C-0113, $141 \mathrm{p}$.

Richardson, D.L. and Brockman, A.R., 1992, Hydrogeology and water quality of the shallow aquifer system in eastern York County, Virginia: U.S. Geological Survey Water-Resources Investigations Report 92-4090, 41 p.

Schubel, J.R., and Zabawa, C.F., 1973, Susquehanna River paleochannel connects lower reaches of Chester, Miles, and Choptank estuaries: Chesapeake Science, v. 14, n. 1, p. $58-62$.
Shideler, G.I., Ludwick, J.C., Oertel, G.F., Finkelstein, K., 1984, Quaternary stratigraphic evolution of the southern Delmarva Peninsula coastal zone, Cape Charles, Virginia: Geological Society of America Bulletin, v. 95, p. 489-502.

U.S. Environmental Protection Agency, 1995, Drinking water regulations and health advisories: Washington, D.C., Office of Water, 11p.

U.S. Geological Survey and National Ocean Service, 1983, Dahlgren quadrangle, Virginia-Maryland: 7.5 minute topographic-bathymetric quadrangle series.

Virginia State Water Control Board, 1973, Ground water of the York-James Peninsula, Virginia: Virginia State Water Control Board Basic Data Bulletin 39, 74 p.

Ward, L.W., 1985, Stratigraphy and characteristic mollusks of the Pamunkey Group (lower Tertiary) and the Old Church Formation of the Chesapeake Group-Virginia Coastal Plain: U. S. Geological Survey Professional Paper 1346, 78 p.

Wershaw, R. L., Fishman, M. J., Grabbe, R. R., and Lowe, L. E., eds., 1987, Methods for the determination of organic substances in water and fluvial sediments: U.S. Geological Survey Techniques of Water-Resources Investigations, book 5, chap. A3, $80 \mathrm{p}$. 